NBER WORKING PAPER SERIES

\title{
IMPORTERS, EXPORTERS, AND MULTINATIONALS: A PORTRAIT OF FIRMS IN THE U.S. THAT TRADE GOODS
}

\author{
Andrew B. Bernard \\ J. Bradford Jensen \\ Peter K. Schott \\ Working Paper 11404 \\ http://www.nber.org/papers/w11404 \\ NATIONAL BUREAU OF ECONOMIC RESEARCH \\ 1050 Massachusetts Avenue \\ Cambridge, MA 02138 \\ June 2005
}

Bernard and Schott thank the National Science Foundation (SES-0241474) for research support. The research in this paper was conducted while the authors were Special Sworn Status researchers of the U.S. Census Bureau at the Boston Census Research Data Center and the Center for Economic Studies Research. Results and conclusions expressed are those of the authors and do not necessarily reflect the views of the Census Bureau or the NBER. This paper has been screened to insure that no confidential data are revealed. The views expressed herein are those of the author(s) and do not necessarily reflect the views of the National Bureau of Economic Research.

(C2005 by Andrew B. Bernard, J. Bradford Jensen, and Peter K. Schott. All rights reserved. Short sections of text, not to exceed two paragraphs, may be quoted without explicit permission provided that full credit, including (C) notice, is given to the source. 
Importers, Exporters, and Multinationals: A Portrait of Firms in the U.S. that Trade Goods Andrew B. Bernard, J. Bradford Jensen, and Peter K. Schott

NBER Working Paper No. 11404

June 2005

JEL No. F10, F16, F23, J21

\section{$\underline{\text { ABSTRACT }}$}

This paper provides an integrated view of globally engaged U.S. firms by exploring a newly developed dataset that links U.S. international trade transactions to longitudinal data on U.S. enterprises. These data permit examination of a number of new dimensions of firm activity, including how many products firms trade, how many countries firms trade with, the characteristics of those countries, the concentration of trade across firms, whether firms transact at arms length or with related parties, and whether firms import as well as export. Firms that trade goods play an important role in the U.S., employing more than a third of the U.S. workforce. We find that the most globally engaged U.S. firms, i.e. those that both export to and import from related parties, dominate U.S. trade flows and employment at trading firms. We also find that firms that begin trading between 1993 and 2000 experience especially rapid employment growth and are a major force in overall job creation.

Andrew B. Bernard

Tuck School of Business at Dartmouth 100 Tuck Hall

Hanover, NH 03755

and NBER

andrew.b.bernard@dartmouth.edu

J. Bradford Jensen

Institute for International Economics

1750 Massachusetts Avenue

Washington, DC 20036-1903

jbjensen@iie.com
Peter K. Schott

Yale School of Management 135 Prospect Street

New Haven, CT 06520-8200 and NBER

peter.schott@yale.edu 


\section{Introduction}

"What does (Art Vandelay) do?"

"He's an importer."

"Just imports? No exports?"

"He's an importer-exporter. Okay?"

Seinfeld, Episode: The Cadillac (2), aired 1996

Art Vandelay is not alone. In 1993, 38.1 million workers were employed by a firm that was directly engaged in the international trade of goods (see Table 1). These workers represent 31.7 percent of the entire civilian workforce and 40.0 of employment outside government and education. ${ }^{1}$ By 2000, the total number of workers at firms that either import or export had risen to 47.9 million or 35.0 percent of the civilian workforce. Indeed, importing and exporting are closely related, more than 50 percent of the firms in the United States that import also export and these firms account for close to 90 percent of U.S. trade.

This paper offers an integrated perspective on globally engaged firms by exploring a newly developed dataset that links international trade transactions to longitudinal data on U.S. enterprises. It extends existing empirical research by examining importers as well as exporters, identifying the activities of multinational firms separately from those of domestic enterprises, and differentiating between arms length and related-party (i.e., intra-firm) trade.

A surge of interest in the microeconomics of international trade and investment has yielded numerous studies of exporters and multinationals. Using firm-level data, empirical researchers have documented that exporting plants and firms represent a small fraction of the total, that firms engaged in exporting have positive performance characteristics (including higher productivity, larger size, greater capital intensity, etc.), that multinational firms pay higher wages than domestic counterparts, and

\footnotetext{
${ }^{1}$ These shares are probably an understatement of the employment at firms directly engaged in goods trade as the linked data employed in this paper cannot associate every export and import transaction with a firm. We discuss this issue in greater detail in the Data Appendix. We also provide a more precise definition of non-government, non-agriculture workforce Section 3 ..
} 
that globally engaged firms undertake more innovation. ${ }^{2}$ To date, these research streams have proceeded largely in parallel with little integration. This paper expands our understanding of internationally engaged firms by examining a number of new dimensions of firm activity, including how many products firms trade, how many countries firms transact with, the characteristics of those countries, the concentration of trade across firms and whether firms import as well as export. We also trace the evolution of these variables, as well as firm survival and employment, over time.

Our ability to answer these questions is made possible by merging two newly available datasets. The first records U.S. import and exports at the transaction level, i.e., according to the customs documents that accompany every shipment of goods crossing a U.S. border. A unique feature of these documents is that they note whether a transaction takes place at arms length or between related parties. ${ }^{3}$ We merge these data with a second, recently developed longitudinal database of U.S. enterprises that tracks almost all private sector firms in the United States as well as their employment over time (Jarmin and Miranda 2002).

The merged dataset provides a more complete picture of firm-level U.S. trade than has heretofore been possible. For example, we can examine the trading activity of firms both inside and outside of manufacturing. We also can identify firms that import as well as firms that export or do both. Perhaps most importantly, unlike most other data sources on trade, we can measure how much of each firm's trade takes place at arms length versus with related parties.

Our analysis uncovers a wealth of interesting results. Some of these reinforce existing findings, while others are entirely new. We find U.S. trade to be concentrated among a very small number of firms. In 2000, for example, the top 1 percent of trading firms (in terms of their trade flows) account for 81 percent of U.S. trade.

\footnotetext{
${ }^{2}$ See Bernard and Jensen (1995, 1999), Doms and Jensen (1998) and Criscuolo, Haskel and Slaughter (2004)

${ }^{3}$ As discussed below, "related party" trade refers to trade between U.S. companies and their foreign subsidiaries as well as trade between U.S. subsidiaries of foreign companies and their foreign affiliates. For imports, firms are "related" if either owns, controls or holds voting power equivalent to 6 percent of the outstanding voting stock or shares of the other organization (see Section 402(e) of the Tariff Act of 1930). For exports, firms are "related" if either party owns, directly or indirectly, 10 percent or more of the other party (see Section 30.7(v) of The Foreign Trade Statistics Regulations).
} 
In terms of product and trading-partner intensity, we find that most importers as well as exporters tend to trade relatively few products and engage in trade with a relatively small number of high-income countries. However, the small number of firms with the greatest product and trading-partner intensity employ large numbers of workers and account for the preponderance of both exports and imports. Over time, the number of firms that export and the number of firms that import rises substantially, from 2.6 and 1.7 percent of all firms in 1993, respectively, to 3.1 and 2.2 percent of all firms in 2000. For exporters, this increase is matched by greater product and trading-partner intensity: between 1993 and 2000, exporters' average number of products increases from 6 to 10 while their average number of destination countries increases from 3.3 to 3.5. For importers, there is little change in either product or trading-partner intensity.

By linking trade transactions to a comprehensive database on U.S. employment we are able to explore the composition of trading firms across goods-producing, wholesale and retail, and service sectors. We find that greatest share of exporting and especially importing firms are found in wholesale and retail trade. However, goods-producing firms account for the majority of exports and imports by value. Multinationals that export are typically goods producers while more than half of multinational importers are in the wholesale and retail sector.

Analysis of firm dynamics reveals that both importing and exporting are associated with greater probability of survival. Both importers and exporters are less likely to exit than firms that do not trade, and firms that engage in some form of related-party trade, i.e. multinationals, have even lower failure rates than firms that trade at arms length. ${ }^{4}$

Employment growth also varies by trading status. We find that trading firms increase employment more rapidly than non-trading firms between 1993 and 2000. We also observe that firms switching their trading status during the sample period have more extreme changes in employment growth than firms with constant trade status. The average firm that opens up to trade between 1993 and 2000 experiences employment growth of close to 100 percent, while the average firm that

\footnotetext{
${ }^{4}$ This definition of a multinational is comparable to that employed by the Bureau of Economic Analysis in its surveys of multinational firms.
} 
quits trading over this period experiences a decline on the order of 10 percent. By comparison, employment growth at continuing traders and continuing non-traders averages between 20 and 25 percent.

The unique characteristics of our data permit identification of a special subset of firms that we refer to as the "most globally engaged" (MGE). MGE firms import as well as export and conduct at least a portion of both types of trade with related parties. Thus, these multinationals have the maximum possible links to the global economy. MGE firms are very influential in U.S. trade and employment. In 2000 they account for nearly 80 percent of U.S. exports and imports, respectively and employ 18 percent of the entire U.S. civilian workforce. They also stand out in a number of other dimensions. First, they are more likely to export to and import from low-income countries than other U.S. exporters and importers. Second, they experience substantially higher growth in exports and imports per worker than nonMGE traders. Finally, over time the MGEs increase their share of intra-firm trade with low-income countries and increase their share of arms-length trade with upperincome countries.

The remainder of this paper is structured as follows. Section 2 documents existing empirical research. Section 3 and the Data Appendix provide a detailed description of our dataset. Section 4 characterizes U.S. trade according to various dimensions of firm activity. Section 5 offers an in-depth view of U.S. multinationals and MGEs. Section 6 summarizes trading firm dynamics. Section 7 concludes.

\section{Existing Research}

We begin by reviewing the existing literature on exporters, importers and multinationals. Our overview is limited to empirical studies that describe their characteristics and the role they play in U.S. trade and employment. We note that there is virtually no research documenting and analyzing importing firms.

In the last decade a substantial body of work has documented the differences between exporters and firms producing solely for the domestic market. Looking at U.S. manufacturing firms, Bernard and Jensen $(1995,1999)$ find that exporters are relatively rare and quite large. Even in tradable goods sectors, the majority of 
plants and firms do not export and non-exporters are an order of magnitude smaller than exporters. In addition, exporters are more productive, more capital-intensive, pay higher wages, employ more technology and have more skilled workers than nonexporting firms even when controlling for industry and geography. ${ }^{5}$ To date, these studies have been largely limited to the manufacturing sector due to the limitations of the underlying data. ${ }^{6}$ In this paper, we summarize export participation and the employment evolution of exporters across all sectors of the U.S. economy from 1993 to 2000.

Recent work by Eaton et al. (2004) extends the analysis of exporting manufacturing firms. These authors examine French firm-level data in 1986 that include information on the destination markets for exporters as well as information about the manufacturing firms themselves. 17.4 percent of the 234,300 French manufacturing firms export; among the exporters, 34.5 percent ship to exactly one country while 19.7 percent export to 10 or more markets and only 1.5 percent export to 50 or more countries. We examine the intensity of export and import activity by U.S.based firms and changes in these intensities over time. In addition, we sort source and destination countries into groups based on income per capita and examine how trading patterns vary according to the global engagement of the firm.

Given the increasing attention to exporters, it is surprising how little work has considered the actions of importing firms. There are no systematic studies of the characteristics of importing firms in the U.S. or other developed economies. MacGarvie (2003) reports some features of large importers using French firm data in her study of the patenting behavior of trading firms. In a subsample of 2757 large firms, she finds differences between firms that trade and those that do not. Specifically, in her sample she compares exporters and non-exporters and then importers and nonimporters and find that both exporters and importers are larger, more productive, more capital-intensive and pay higher wages. While she notes that exporters are

\footnotetext{
${ }^{5}$ Similar evidence on exporters has been documented for other countries, e.g. Bernard and Wagner (1997) - Germany, Clerides, Lach and Tybout (1998) - Colombia, Mexico and Morocco, Aw, Chung and Roberts (2000) - Korea and Taiwan, Delgado, Farinas, and Ruano (2002) - Spain among many others.

${ }^{6}$ The general data source for such studies are censuses of manufacturing plants or firms. e.g. the U.S. Census of Manufactures.
} 
likely to also be importers, she does not separately examine firms that both export and import. Given the nature of our data, we are able to provide a first look at the extent of importing by U.S. firms, the distribution of activity across importers, and their role in the overall economy.

There is also an enormous literature on multinational firms which we cannot hope to adequately summarize here. As our focus is on the exports, imports, and employment of U.S.-based firms, we limit our discussion to studies of multinationals based in the U.S., either U.S. parents or U.S. affiliates of foreign firms, that also examine these areas.

Two recent papers by Slaughter (2004a,b) using aggregate data from the Bureau of Economic Analysis summarize employment trends of multinationals operating in the United States. Although these papers focus on two different types of multinationals based in the U.S., both report sizable increases in employment at multinationals during the 1990s. Slaughter (2004a) finds that U.S. employment of U.S. multinationals increases from 17.5 million to 23.9 million from 1993 to 2000 . Looking at U.S. affiliates of foreign parents, Slaughter (2004b) reports that employment rises from 3.9 million in 1992 to 5.4 million in 2002. Using our firm-level data, we are able to decompose the overall changes in U.S. employment from 1993 to 2000 by the trading activities of the firm. ${ }^{7}$

Another body of work has documented differences between multinational and domestic firms. Doms and Jensen (1998) use plant level data from the Census Bureau and the Bureau of Economic Analysis to examine the characteristics of plants owned by multinational companies. Doms and Jensen find that U.S. plants owned by MNCs (whether U.S. MNCs or foreign-owned MNCs) are larger, more capital intensive, more skill intensive, pay higher wages, are more technology intensive, and are more productive than non-MNC plants.

A related literature focuses on multinational trade. Zeile (1997) summarizes the role of multinationals and intra-firm trade in overall U.S. trade using data from firmlevel surveys conducted by the Bureau of Economic Analysis. Zeile (1997) reports little trend in the share of intra-firm exports and imports in total U.S. exports and

\footnotetext{
${ }^{7}$ Our linked trade-firm data does not provide information on the nationality of ownership so we are unable to separately examine the activities of U.S.-based versus foreign-based multinationals.
} 
imports from 1977 to 1994 . He also reports that U.S. parents have seen their share of trade decrease even as their trade has shifted toward intra-firm activity. Using trade transaction data, we are able to examine the role of multinationals in U.S. exports and imports and we report separate results for total trade and related-party trade throughout the paper.

Another collection of recent papers using firm-level data has examined the decision by U.S. multinationals to export intermediate goods to their foreign affiliates. Hanson et al (2004) find that higher trade costs, higher wages for unskilled labor and higher corporate tax rates reduce demand for intermediate inputs exported by U.S. parents. Borga and Zeile (2002) also use data on U.S. MNCs collected by the U.S. Bureau of Economic Analysis in the 1994 benchmark survey. They report that the share of intermediate goods exported from U.S. parents to their affiliates increased from 8 percent of total U.S. exports in 1977 to 15 percent in 1999. Borga and Zeile (2002) are primarily concerned with analyzing vertical versus horizontal multinational structure and consider the role of firm, industry and country effects on the share of imported intermediates in total sales of affiliates.

One of the main goals of this paper and further research using the transactionfirm linked data is the development of a deeper understanding of the decision to trade at arms length or inside the firm. The role of arms-length versus intra-firm trade has been the focus of several recent theoretical papers. Antràs (2003) develops a trade model with firm boundaries set by incomplete contracts and property rights to examine the variation in intra-firm trade across destinations and sectors in U.S. trade. Antràs and Helpman (2004) study the importance of within-sector heterogeneity and industry characteristics on the prevalence of integrated versus arms length organizational forms in a model North-South trade. Grossman and Helpman (2004) develop a model of firm organization and location across borders that focuses on problems in contracting between principals and suppliers or employees in a world with heterogeneous firms. Grossman et al. (2004) develop a model of heterogeneous firms in the presence of variation in industry characteristics, the cost of transport, and regional demand. 


\section{Data}

This paper exploits a new dataset which links individual trade transactions to U.S.-based firms. This dataset is derived from two sources. The first is a database of all U.S. trade transactions assembled by U.S. Customs (imports) and the U.S. Census Bureau (exports). These data cover all shipments of goods that crossed into or out of the United States between 1992 and 2000 inclusive. In this paper, we make use of data from the years 1993 and 2000.

The second data source is the Longitudinal Business Database (LBD) of the Census Bureau. ${ }^{8}$ These data record employment and survival information for all U.S. establishments outside of agriculture, forestry and fishing, railroads, the U.S. Postal Service, education, public administration and several other smaller sectors. Total employment in the sectors covered by the LBD rose from 95 million to 115 million from 1993 to $2000 .^{9}$

For the firm-level summary that is the focus of this paper, we aggregate imports and exports for each firm according to (a) product, (b) country (source or destination), (c) relationship (intra-firm or arms length), and (d) year. ${ }^{10}$ We also aggregate the establishment-level employment data in the LBD up to the level of the firm, retaining information on the firm-level distribution of employment across sectors. We link the two datasets at the level of the firm. This link allows us to match the inward and outward trade transactions by the dimensions noted above to the appropriate firms. This linked data covers more than three quarters of U.S. imports and exports in each year. All of the results reported below are with respect to this linked dataset unless otherwise noted. We also note that all dollar amounts reported in this paper are nominal.

\footnotetext{
${ }^{8}$ See the Data Appendix for more information on all the data sources and the sectors covered. See Jarmin and Miranda (2002) for an extensive discussion of the LBD and its construction.

${ }^{9}$ Total employment in the U.S. increases by 16.7 million from 120.2 million in 1993 to 136.9 million in 2000 (Economic Report of the President 2005).

${ }^{10}$ Every export or import transaction records whether the transaction takes place between "related parties". See the Data Appendix for the definition of related-party transactions for exports and imports. We use the terms 'intra-firm' and 'related-party' interchangeably in this paper. All firms that have a related-party transaction (export, import or both) during the year are described as 'multinationals' or related-party firms.
} 
Table 2 reports the number of trading firms as well as the total number of firms in each year of the sample. Firms are categorized according to whether they export, import, or both export and import, as well as according to whether they engage in these activities as multinationals. We categorize firms as multinationals if at least a portion of their trade is with related parties. Thus, "Multinational Exporters" differ from "Exporters" in that the former have non-zero shares of related-party trade. As indicated in the table, trading firms are relatively rare vis-a-vis all firms, and multinationals are rarer still. The data indicate that firms that export are more prevalent than firms that import, but that the numbers of both types of firms engaged in international trade are increasing three to seven times faster than the overall number of firms. In 2000, 2.6 percent of firms export, 1.7 percent of firms import, and 0.9 percent of firms both import and export. Fewer than a quarter of exporters or importers are multinationals.

U.S. trade is heavily concentrated among a very small number of firms. Indeed, trade concentration is much more extreme than either production or employment. Table 3 reports the distribution of exports and imports across firm percentiles in both 1993 and again in 2000. The top panel summarizes the share of U.S. trade and employment at firms in the top 1, 5, 10, 25, and 50 percentiles of total trade, i.e. imports plus exports. As indicated in the table, trade concentration is remarkably high, with the top 1 percent of traders (1732 firms) accounting for 77 percent of exports plus imports in 1993. ${ }^{11}$ These firms are also among the largest in the economy, accounting for 15.1 percent of employment or 14.3 million workers. Over time trade is becoming increasingly concentrated at the top firms. By 2000, the largest 1 percent of trading firms (2245 firms) control almost 81 percent of all trade. ${ }^{12}$ The second and third panels of Table 2 report concentration among importers and exporters separately. Importers show a similar if slightly smaller degree of concentration than exporters. For both imports and exports, the smallest 75 percent of firms are responsible for less than 2 percent of imports and exports, respectively.

\footnotetext{
${ }^{11}$ These firms control equal shares of exports and imports.

${ }^{12}$ Note that while the shares of the top 5, 10, 25, and 50 percent of firms rose, these increases were due entirely to growth in shares at the very top of the distribution.
} 


\section{Importers and Exporters}

In this section we characterize U.S. firm-level trade according to several dimensions of activity. First we examine firms' product and trading-partner intensity, i.e. the number of products firms trade and the number of countries with which they trade. We then segment firm trade according to the income level of source and destination countries. Finally, we categorize trading firms' global engagement and identify the set and influence of firms that we define to be the most globally engaged (MGE).

This section highlights several noteworthy trends. First, we show that importers as well as exporters tend to trade relatively few products with a relatively small number of countries. Second, we show that most trading firms import from or export to relatively high-income countries, and that importers are relatively more likely to trade with lower-income countries than exporters. Third, we find that a substantial and growing fraction of trading firms are in service sectors, particularly wholesale and retail, though the majority of MGEs, multinationals that export as well as import, are found in manufacturing. Finally, we demonstrate that MGE firms dominate U.S. trade flows and employment among trading firms.

\subsection{Firms' Product-Intensity}

Exporters generally export fewer products per firm than importers import, but exporters are catching up over time. Between 1993 and 2000, the average number of products exported by exporters rose from 6.1 to 8.9 products per firm. The average importer sources 10 products in both periods.

Table 4 reports the distribution of firms, export and import value, intra-firm trade, and employment according to the number of products firms import or export in each year. Each cell of the table reports the share of one of these variables accounted for by all firms exporting or importing the number of products noted at the left. As indicated in the table, exporters are more likely to trade just a single product and are less likely to export more than ten products than importers, though in both cases single-export and single-import firms are in the majority. The vast majority of trade value and related-party trade value, on the other hand, increasingly 
flows through firms that export or import the largest number of products. In 2000, just 6 percent of exports, and 2 percent of related-party exports are accounted for by firms shipping fewer than 10 products. Similar figures are reported for imports.

Export product intensity is increasing over time while import product intensity is basically flat. The share of firms exporting just one product falls from 41.2 percent in 1993 to 36.2 percent in 2000 while the share of firms exporting ten or more products increases from 11.6 percent to 17.4 percent. This shift among exporters occurs even as the number of exporting firms rises by 28 percent and the number of exporters as a fraction of all U.S. firms increases from 2.6 percent to 3.1 percent (see Table 2).

The final block of columns in Table 4 reports the share of U.S. employment represented by firms that export and import relative to firms that serve the domestic market only. The first row of these columns reveals that the share of workers employed by firms that do not trade, while high in both periods, has fallen with time. This decline is evident across both exporters and importers, but is more pronounced among exporters (a decline of 63.7 to 60.6 percent versus 67.7 to 67.0 percent). The number of workers employed by firms that export the largest number of products grows faster (34 percent) than the overall workforce (20 percent) between 1993 and 2000.

Table 5 reports the average employment as well as trading volume per firm and per worker by the number of products firms trade. As expected, average employment per firm is positively correlated with the number of products traded. Firms that export the largest number of products are more than ten times larger than exporters exporting just one or two products. Over time the average firm size for the most prolific exporters has fallen from 1477 employees to 1025 employees. Over the same interval, these firms experience a slight decline in export value per firm (roughly $\$ 20$ million in both years) and a 44 percent increase in export value per worker, from $\$ 13.4$ to $\$ 19.3$ thousand.

These results demonstrate that, over time, trade is becoming more concentrated at firms sending and receiving the most products across U.S. borders. This rise in concentration stems both from an increase in the number of firms engaged in multiproduct trade as well as a dramatic increase in exports and imports per employee 
at those same firms. Firm size is actually decreasing for this group.

\subsection{Firms' Trading-Partner Intensity}

This section examines the changing nature of the firms' global engagement in terms of their trading-partner intensity. The average number of countries with which exporters trade is rising over the sample period, from 3.3 to 3.5. For importers, trading-partner intensity is flat at an average of 2.8 countries per firm in both years. Table 6 summarizes this activity. Here, as with product intensity, there is substantial variation across firms. More than half of both importers and exporters transact with just a single foreign country, while substantially fewer firms transact with ten or more countries. Here, too, the dominant portion of exports and imports as well as related party trade flow through firms transacting with the largest number of countries.

Trading partner intensity increases slightly over time for importers and more so for exporters. Between 1993 and 2000 the share of exporters transacting with just a single country declined from 60.3 percent to 56.6 percent, while the analogous movement for importers is a decline from 52.1 percent to 51.3 percent. Similarly, the share of trade, the share of related-party trade and the share of employment all increase over time for firms trading with more than a single country.

Average firm employment as well as average trading value per firm and per worker by trading-partner intensity are reported in Table 7 . As above, average employment is positively correlated with the number of countries with which firms trade but is declining with time. For both exporters and importers, average value per firm and per worker for firms trading with the largest number of countries increases substantially between 1993 and 2000 .

Trade is also becoming more concentrated at firms with the most trading partners. Again, this rise in concentration stems both from an increase in the number of firms with multiple trading partners as well as a dramatic increase in exports and imports per employee at those firms even as firm size has been shrinking. 


\subsection{The Income Level of Firms' Trading Partners}

In this section we examine the types of countries with which firms trade. Our analysis makes use of a classification developed by the World Bank that segments countries according to whether their per capita income is low, lower-middle, uppermiddle or high. ${ }^{13}$ Use of these groups to classify trading partners is consistent with existing research indicating a strong relationship between income per capita and both variety-driven intra-industry trade and endowment-based comparative advantage. Though most trade is conducted with firms in upper-income countries, a relatively greater share of importers and import value is associated with lowermiddle-income countries. Over time, the share of trade with middle- and low-income countries is rising.

The first two columns of Table 8 report the share of exporters and importers that trade with at least one country of each type in 1993 and 2000. In both years, the largest share of both exporters and importers trade with at least one upper-income country, though these shares decline over time for both groups of firms. In 2000, 85.6 percent of exporters and 79.9 percent of importers transact with at least one upper-income country, down from 88.3 percent and 85.5 percent in 1993, respectively. ${ }^{14}$ The middle two rows of each panel in Table 8 reveal that lower-middle-income countries are substantially more important for imports than for exports. More than 30 percent of importers source goods from at least one lowermiddle country in 1993, rising to more than 38 percent in 2000. This difference is likely driven by China, which is defined by the World Bank to be a lower-middle country.

The largest shares of export and import value are destined for upper-income countries. In 1993, 72.2 percent of exports and 69.7 percent of imports are ac-

\footnotetext{
${ }^{13}$ We use the 2003 classification for both years of our sample. The income cutoffs for the four groups are $\$ 765$ or less, $\$ 766$ to $\$ 3,035, \quad \$ 3,036$ to $\$ 9,385$ and $\$ 9,386$ or more. For a list of countries and their World Bank income group, see http://www.worldbank.org/data/countryclass/countryclass.html. The Data Appendix describes modifications made to this data.

${ }^{14}$ Note that the cumulative sum of shares in the first two columns of the table do not sum to 100 percent because firms may trade with countries of different income levels, and therefore be included in more than one row of the table.
} 
counted for by upper income countries while low-income countries represented just 1.5 percent and 2.6 percent of trading value, respectively. ${ }^{15}$ Lower-middle income countries are relatively more important for imports than for exports. Over time, the export and import value shares represented by both middle income groups increases the most for both imports and exports, by 4.4 percentage points for exports and 8.6 percentage points for imports.

The middle four columns of Table 8 report the employment shares of firms as well as average employment per firm according to the types of countries with which they transact. While most exports and most exporters are engaged in trade with upper-income countries, average employment is greatest for firms shipping to lowincome destinations. Average firm size falls systematically as the income of firms' trading partners increases. This finding suggests that the largest firms are the first to enter markets that are least similar to the United States.

\subsection{Firms' Sector Affiliation}

Typically imports and exports are categorized according to the product being traded. In this section we focus on firms and ask how much trade is controlled by firms in three broad sectors: goods producing firms, wholesale and retail, and service establishments. We provide the first direct evidence on the distribution of trade by firms across sectors.

We first place firms in one of five groups based on the activities of their operations in the U.S.. Each establishment within a firm is categorized by a primary industry designation, i.e. a four-digit Standard Industrial Classification code. We group these codes into three sectors: Goods, i.e. manufacturing, mining, and agriculture, Wholesale \& Retail trade, and Services, i.e. all remaining industries. We then calculate the share of employment within the firm that is in each of these three aggregate sectors. Firms are assigned to one of five groups - Goods, Wholesale and Retail, Services, Goods Plus, and Other - depending upon these shares. Firms with at least 75 percent of their employment in manufacturing, mining, and agriculture are designated as Goods. Firms with at least 75 percent of their employment in

\footnotetext{
${ }^{15}$ Note that export and import value shares do sum to 100 percent because export and import value can be observed at the transaction level.
} 
Wholesale and Retail or Services are assigned to those sectors respectively. Firms with 25 to 75 percent of their employment in manufacturing, mining, and agriculture are assigned to Goods Plus. All remaining firms, i.e. firms with less than 25 percent employment in Goods and less than 75 percent employment in either Wholesale \& Retail or Services, are assigned to Other.

Table 9 shows the distribution of firms, employment and trade by firms' sector affiliation. In 2000, Goods, Wholesale \& Retail, and Services account for 99.9 percent of firms $(7.3,23.2$, and 69.4 , respectively) and 95.5 percent of employment (16.2, 24.9, and 54.4 respectively). Exporters are most likely to be in Goods or Wholesale \& Retail (35.2 and 40.8 percent, respectively) with Services accounting for 22.6 percent. However, most exports (by value) originate in firms with a heavy presence in Goods: 62.8 percent at Goods firms and 19.2 percent at Goods Plus firms even though the latter sector comprises a relatively small number of firms. Exports per firm in the Goods Plus category average more than $\$ 61$ million in 2000.

Understandably, a greater share of importers than exporters are in Wholesale \& Retail (62.7 percent in 2000), followed by Goods and Other (24.9 and 20.4 percent, respectively). Import value is also increasingly concentrated among Goods and Goods Plus firms (40.1 and 21.6 percent, respectively), though the level of imports due to Wholesale \& Retail firms (27.3 percent in 2000) is substantially higher than for export value (10.4 percent). Related-party trade is most heavily concentrated at production-based firms: 90.5 percent of related-party exports and 74.5 percent of related-party imports are at Goods and Goods Plus firms in 2000.

Though employment rises over the sample period for firms in all sectors except Other, employment growth is disproportionately large among trading firms in the Wholesale \& Retail and Service sectors. While employment in Goods firms rises 3 percent, employment at Wholesale \& Retail and Services firms grows by 18 and 30 percent, respectively.

These results point to a shift in activity in the tradeable goods sectors. While goods-producing firms still dominate the landscape, trading firms are increasingly engaged in wholesale and retail trade. 


\subsection{Firms' "Global Engagement"}

In previous sections we found that the largest firms account for the preponderance of trade and are the most likely to trade with the poorest countries. In this section we define firms' global engagement according to the breadth and depth of their global interaction. Firms may export, import, do both or neither. Firms that both export and import have greater breadth of global engagement than firms that do not trade or firms that just export or just import. Trading firms may also trade via arms length transactions or with related parties, with the latter reflecting greater depth of global engagement than purely domestic firms. We define the most globally engaged (MGE) firms as those which both export to and import from a related foreign affiliate.

Table 10 reports the distribution of exporters and importers according to their export and import relationships. Results are reported in two panels, with the upper panel summarizing all firms that export and the lower panel summarizing all firms that import. The export and import relationships noted in the first two columns roughly characterize increasing global engagement. For example, arms-length (AL) exporters that do not import are the least globally-engaged exporters, i.e. they are "less" globally engaged that exporters that also import and have at least some part of one of their relationships encompassing trade with related parties.

As indicated in the table, the MGE firms comprise a very small share of trading firms, 6 percent of exporters and 9 percent of importers. The overall global engagement of exporters is increasing with time. Between 1993 and 2000, the share of exclusively arms-length exporters declined from 59 percent to 53 percent. Exclusively arms-length importers are 44 percent and 43 percent of all importers, respectively, in the two years.

Table 11 summarizes trading firms according to both their level of global engagement and the income level of countries with which they trade. The first block of columns reports results for exporters and the countries to which they send goods while the second block of columns reports results for importers and the countries from which they source products. In 1993, for example, 3 percent of exporters that only export and only via arms length trade shipped goods to at least one country 
with the lowest-level of income. The analogous number for importers is 7 percent. ${ }^{16}$

Table 11 shows that trading firms are most likely to transact with upper-income countries regardless of their level of global engagement, reinforcing the message of Table 8 above. More interestingly, the table reveals that the most globally engaged firms (MGEs), i.e. those that both import and export and engage in at least some trade with related parties, are the most likely to export to countries of all types. While just 4 percent of exclusively arms length exporters export to a low-income country in 2000, for example, 18 to 26 percent of the most globally engaged firms do so that year. These differences between the least and most globally engaged firms are generally more pronounced for exporters than for importers, but are present for both groups of trading firms. Table 11 also shows that the greater proclivity of importers to trade with lower-middle income countries increases with their global engagement.

Table 12 reports export and import value shares according to the same typology used in Table 11.17 As expected, upper-income countries account for the largest share of trade value. However, an interesting difference emerges between low and low-middle trading partners versus upper and upper-middle partners. Looking across types of firms, we find that poorer countries account for a relatively larger share of trade at the least globally engaged firms. In 2000, arms length exporters ship 20 percent of their goods to the two lowest income groups and arms length imports source 40 percent of their imports from the same countries. In contrast, the most globally-engaged multinationals send just 16 percent of their exports and source 16 percent of their imports from these same countries.

\section{Multinationals}

Multinationals play a key role in U.S. employment and trade patterns. Employment at multinationals accounts for 33.3 million workers or 29.1 percent of the non-governmental workforce in 2000, up from 25.5 million workers and 26.7 percent

\footnotetext{
${ }^{16}$ As noted in the table, the percentages for any given level of global engagement do not sum to 100 percent because firms may trade with countries of more than one income level.

${ }^{17}$ As noted in the table, the export or import value percentages for each export and import relationship pair sum to 100 percent because trade can be observed at the firm-transaction level.
} 
in 1993 (Table 13). The increase of employment at multinational firms represents more than 40 percent of the net job creation in the private sector over period highlighting the disproportionate role of multinationals as a source of job creation.

Multinationals also mediate a substantial majority of U.S. trade. This role is highlighted by Figure 1, which reveals that roughly 90 percent of U.S. exports and imports in our sample flow through multinational firms. Each column in the figure reports the total trade by either exclusively arms length trading firms or multinationals in 1993 or 2000 . The first four columns summarize imports while the second four columns summarize exports. The columns for multinationals note the share of their trade that is conducted at arms length as well as the share conducted inside the firm.

As indicated in the Figure, multinationals' share of total trade in our sample increases over time, rising 2.0 percent for imports and 4.0 percent for exports. Within multinationals, the breakdown of trade between intra-firm and arms length transactions remains relatively constant over time. For imports, the share of intra-firm trade in the linked dataset rises slightly from 48.4 percent in 1993 to 51.7 percent in 2000. For exports, it falls from 35.6 to 32.6 percent.

Figures 2 and 3 break down U.S. exports and imports, respectively, by the global engagement categories employed in Section 4.5.. A large majority of both exports and imports are due to firms that both export to and import from related-parties, i.e. MGEs. In both cases these shares increase over time, from more than 70 percent in 1993 to just under 80 percent in 2000. The role of MGEs in both employment and, especially, trade is on the rise, driven in large part by a large increase in the number of these most globally engaged firms.

Within multinationals, the share of trade that is with related parties varies widely. Table 14 reports the distribution of multinational firms and related-party trade according to related-party-trade intensity, i.e., whether related-party trade accounts for less than 25 percent, between 25 percent and 75 percent, or more than 75 percent of multinationals' trade, respectively. For a large share of multinationals, related-party trade makes up less than a quarter of total trade.

Among firms with higher related-party-trade intensity, there are substantial differences between exporters and importers. About a quarter of multinationals have 
intra-firm trade shares between 0.25 and 0.75. Exporters in this group account for a majority of related-party trade, 56.6 percent in 1993 while importers in this group, by contrast, account for a much smaller share of intra-firm trade, 30.8 percent. The roles are reversed for multinationals reporting the highest level of related-party trade intensity. Exporters with intra-firm trade shares greater than 75 percent are only 22 percent of all exporting multinationals in 1993 and their share of overall intra-firm exports is relatively low, 36.7 percent. Firms with intra-firm import shares greater than 75 percent are about one third of importing multinationals but dominate overall intra-firm imports, 66.0 percent of total related party imports in 1993.

There are significant changes over time in the share of firms and intra-firm trade in the three groups of multinationals. In addition we find different trends for exports and imports. Between 1993 and 2000, the share of multinationals in the lowest related-party-trade intensity category increases from 53.0 and 41.9 percent to 63.9 and 43.1 percent for exporters and importers, respectively. However, these firms are responsible for a relatively small, albeit rising, amount of related-party trade in both years, less than 10 percent for exports and less than 4 percent for imports. One potential explanation for these trends is the substantial increase in the numbers of multinationals during the period. New multinationals may have smaller share of related party trade than established firms.

The share of exports among firms with intermediate related-party-trade intensity rises to 68.3 percent in 2000 , while importers in this group account for a smaller share of imports in 2000, 25.9 percent. The roles are reversed for multinationals reporting the highest level of related-party trade intensity with the share of intrafirm trade falling to 13.1 for exporters and rising to 70.6 percent for importers in 2000 .

\subsection{The Most Globally Engaged Firms (MGEs)}

The most globally engaged firms are multinationals that both import and export with related-parties. In this section we describe the activities of this set of firms in greater detail.

Table 15 breaks out the number of firms, trading value and employment of the 
most globally engaged firms according to the sectoral activity of the firm. The distribution of MGEs across sectors is sharply different from the overall distribution of firms reported in Table 9. Firms with a major presence in goods production, either Goods or Goods Plus, account for more than 50 percent of MGE firms. In contrast goods-producing firms account for under 10 percent of all U.S. firms and 35 percent of non-multinational firms that import and export. Wholesale and Retail and Services firms are 10 percent and 37 percent of MGEs respectively in 2000.

The importance of Goods and Goods Plus firms among the most globally engaged firms is even more evident when we consider their share of trade flows. Goodsproducing firms control an increasing share of total trade by MGEs, 91 percent of exports and 72 percent of imports in 2000. Intra-firm trade by MGEs is even more concentrated at Goods and Goods Plus firms. Their share of MGE intra-firm imports rises to 77 percent in 2000 while their export share increases to 93 percent. These increases in export and import shares occur even as employment is shifting towards MGEs in the Wholesale and Retail sector. The overall picture painted by Table 15 is of the continued and increasing importance of goods-producing firms in U.S. trade flows controlled by MGEs.

Table 16 provides a view of the distribution of MGE activity across countryincome groups. The first two columns report the share of MGE intra-firm exports and imports by source or destination country where, as before, countries are grouped by per capita income. The last two columns report the share of total U.S. exports and imports controlled by MGEs. Looking across country groups, we find that intra-firm trade shares for MGEs generally are rising with the income of the source or destination country. However, there have been several notable changes over time. For both exports and imports, intra-firm trade shares are rising for the lower income countries. In contrast, intra-firm exports to upper income destinations fall for MGEs, while imports show small increases in intra-firm trade even for the upper income source countries. At the same time, Table 16 reveals that while the importance of trade with the most globally engaged firms is falling for low-income countries, it is rising for middle- and high-income countries.

Throughout this paper, we have found that multinationals that both export to and import from a related party play a large role in total U.S. trade. The results 
here suggest these firms are still heavily associated with goods production and that the extent of their intra-firm trade varies substantially with the characteristics of the source or destination country.

\section{Importer and Exporter Dynamics}

In this section we examine trading-firm versus non-trading-firm survival and employment growth rates as well as changes in firms' trading status between 1993 and 2000. We find that both importing and exporting are positively associated with survival and that multinationals have an even higher probability of survival than the larger group of trading firms. We also show that employment growth varies by trading status, with firms that transition from being non-traders to traders expanding the fastest.

\subsection{Firm Survival Dynamics}

Table 17 decomposes the overall growth of trading firms between 1993 and 2000 into several categories. Each row of the table focuses on a different, non-mutually exclusive subset of trading firms. In the upper panel, the first and last columns of the table report the number of firms in each subset of firms at the beginning and end of the sample period. The second and third columns of the top panel report the number of 1993 firms that shutdown and the number of new firms that enter between 1993 and 2000 respectively. The fourth, fifth and sixth columns of the upper panel report on firms that exist in both years according to their trading status: trade in both years, start trading and stop trading respectively. The final row of the upper panel reports an analogous breakdown for all firms. The lower panel of the table expresses all of these firm counts as percentages of their 1993 values.

As indicated in the Table, survival rates for firms vary according to their trading status. Exit rates for every type of trading firm (33 to 39 percent) are significantly lower than the failure rate for all firms (47 percent). Among trading firms, multinationals have higher survival probabilities than their non-multinational counterparts, while MGE firms, i.e., multinationals that both import and export, have the highest 
survival rate of all. The relatively low failure of MGE firms is one contributor to the rising share of MGE firms over time.

\subsection{Firm Trading-Status Dynamics}

Table 17 reveals that another factor in the rising share of globally engaged firms over the sample period is the transition of some continuing firms from non-trading to trading status between 1993 and 2000. The first row of the table, for example, indicates that 49,035 firms, or 1.9 percent of the 2.6 million continuing firms that did not trade in 1993, become exporters over the sample period. The share continuing firms that move in the opposite direction, i.e., that shift from being exporters in 1993 to be non-exporters in 2000, by contrast, constitute a much small percentage (1 percent). Similar relative magnitudes are found for all forms of global engagement

- the share of continuing firms that disengage from international trade ranges from roughly one-third to three-quarters of the share of continuing firms that start trading. Furthermore, the levels and shares of firms that start engaging in international trade exceed the number of international traders that exit. Both the higher likelihood of firms switching into trade relative to switching out and the higher number of new entrants engaged in international trade spur increases in the overall share of globally engaged firms.

\subsection{Firm Employment Dynamics}

Table 18 decomposes 1993 to 2000 employment growth along the same dimensions as Table 17. As indicated in the last row of each panel, aggregate employment grows by 19 million workers, or 20 percent, over the sample period. Employment at trading firms generally grows even faster. Exporters and multinational exporters experience the highest employment growth rates, at 30.2 and 32.3 percent respectively. The higher employment growth in the exporters category is due to both employment growth at continuing firms that export and continuing firms that start to export. The net employment effect of the exit of exporters and the entrance of new exporting firms is negative (as exiting firms tend to be larger than entrants). Employment growth across importers and multinational importers is somewhat lower, at 22.3 
and 19.5 percent, respectively, while employment growth across all firms that both export and import is 27.4 percent while multinationals that both import and export expand by 20.3 percent.

Table 19 shows the employment growth at firms by trading status. The most striking feature is the employment growth rates at firms that change their trading status. Firms that switch from being non-traders in 1993 to traders in 2000 experience the largest gains in employment growth. This growth is highlighted in Table 19 , which reveals that firms that become exporters over the sample period increase their employment by 94.3 percent, from 3.9 million to 7.4 million. ${ }^{18}$ Firms that become importers or switch into both importing and exporting experience similar increases. Table 19 also reports the employment declines experienced by firms that exit international markets. Firms that quit exporting, quit importing, and quit both importing and exporting witness declines of 12.3, 16.6 and 10.1 percent, respectively.

Table 19 also reports the employment growth rates at firms that maintained the same status in both periods. For continuers, trading firms that maintain their trading status typically have lower employment growth rates than non-trading firms that maintain their trading status.

\section{Conclusions}

This paper provides a new integrated portrait of firms in the U.S. that trade goods. We document the increasing globalization of U.S. firms by linking data on U.S. international trade transactions to a comprehensive census of U.S. enterprises. U.S. firms' global engagement is increasing in a number of dimensions. First, there is substantial growth in the number of firms that export, import and trade with related parties. Second, firms increasingly send a greater number of products to a larger set of more diverse countries. Third, trading firms are becoming increasingly more import and export intensive in terms of their dollar value of trade per worker. We show that the most globally engaged firms, i.e., those that export as well as import from related parties, have substantial influence: they both account for a

\footnotetext{
${ }^{18}$ This is consistent the findings of Bernard and Jensen $(1999,2004)$ that exporters grow significantly faster than non-exporters.
} 
significant share of U.S. employment and mediate a dominant portion of U.S. trade flows.

The data employed in this paper can be used to answer a wide-ranging set of questions about the decisions of firms engaged in international commerce. By being able to separately identify arms-length and intra-firm transactions, we can understand the response of multinationals to financial crises, transfer pricing inside the firm, the role of firm, product and country characteristics in the decision to outsource, pricing-to-market and pass-through responses to exchange rate movements, the role of multinationals in job creation, and the importance of imports and exports in firm performance among many others. 


\section{References}

Antràs, Pol, (2003), "Firms, Contracts, and Trade Structure," Quarterly Journal of Economics, 118 (4), November, pp. 1374-1418.

Antràs, Pol and Elhanan Helpman, (2004), "Global sourcing", Journal of Political Economy 112: 552-580.

Aw, Bee Y., S. Chung, and Mark J. Roberts M, (2000), "Productivity and turnover in the export market: Micro-level evidence from the Republic of Korea and Taiwan (China)", World Bank Economic Review, 14 (1): 65-90

Baldwin, John R. and Wulong Gu, (2003), "Export-market participation and productivity performance in Canadian manufacturing", Canadian Journal of Economics, 36 (3): 634-657

Bernard, Andrew B. and J. Bradford Jensen. (1995). "Exporters, Jobs, and Wages in U.S. Manufacturing, 1976-1987." Brookings Papers on Economic Activity, Microeconomics. Washington DC.

Bernard, Andrew B. and J. Bradford Jensen. (1999). "Exceptional Exporter Performance: Cause, Effect or Both?" Journal of International Economics Vol. 47, No. 1: 1-25.

Bernard, Andrew B. and J. Bradford Jensen. (2004). "Exporting and Productivity in the USA" Oxford Review of Economic Policy, 2004, Vol. 20, No. 3, 343-357.

Bernard Andrew B. and Joachim Wagner (1997), "Exports and success in German manufacturing", Weltwirtschaftliches Archiv, 133 (1): 134-157

Borga, Maria and William J. Zeile, (2004), "International Fragmentation of Production and the Intrafirm Trade of U.S. Multinational Companies", Bureau of Economic Analysis Working Paper 2004-02.

Clerides, Sofronis K., Saul Lach, and James R. Tybout, (1998) "Is learning by Exporting Important? Micro-dynamic Evidence from Colombia, Mexico, and Morocco." Quarterly Journal of Economics, Vol. 113, No. 3, 903-947. 
Chiara Criscuolo, Jonathan E. Haskel and Matthew J. Slaughter (2004), "Why Are Some Firms More Innovative? Knowledge Inputs, Knowledge Stocks, and the Role of Global Engagement", Tuck School of Business mimeo.

Delgado M.A., J.C. Farinas, and S. Ruano, (2002), "Firm productivity and export markets: a non-parametric approach", Journal of International Economics, 57 (2): 397-422

Doms, Mark E. , and J. Bradford Jensen, (1998) "Comparing wages, skills and productivity between domestically and foreign-owned manufacturing establishments in the United States" in R.E. Lipsey R.E. Baldwin and J.D. Richardson, editors, Geography and Ownership as bases for economic accounting, Universtiy of Chicago press, 235-258.

Economic Report of the President, (2005) U.S. Government Printing Office, Washington, DC 20402-0001

Grossman, Gene M. and Elhanan Helpman, (2004), "Managerial incentives and the international organization of production", Journal of International Economics $63,237-262$.

Grossman, Gene M., Elhanan Helpman, and Adam Szeidl, (2004), "Optimal Integration: Strategies for the Multinatinal Firm", CEPR Working Paper No. 4477.

Hanson, Gordon H., Raymond J. Mataloni, and Matthew J. Slaughter, (2004), “ Vertical Production Networks in Multinational Firms", revision of NBER Working Paper \#9723.

MacGarvie, Megan, (2003), "Do Firms Learn from International Trade? Evidence from Patent Citations and Micro Data", Boston University School of Management mimeo.

Slaughter, Matthew J. (2004a), "Globalization and Employment by U.S. Multinationals: A Framework and Some Facts" Daily Tax Report, March 26.

Slaughter, Matthew J. (2004b), "Insourcing Jobs: Making the Global Economy Work for America" Organization for International Investment, mimeo, October. 
Zeile, William J., (1997), "U.S. Intrafirm Trade in Goods", Survey of Current Business, 77:2, February, 23-38. 


\section{A Data Appendix}

\section{A1. Data Sources}

In this paper, we make use of transaction level import and export data linked to information on firms in operation in the U.S..

The transaction data used in this paper are compiled from administrative records from the official U.S. import and export merchandise trade statistics. The merchandise trade data are a complete enumeration of documentation collected by the U.S. Customs Service and are not subject to sampling error. Quality assurance procedures are performed at every stage of collection, processing and tabulation; however, the data are subject to non-sampling errors, including undocumented shipments, timeliness, and data capture errors.

The establishment and firm data used in this paper are compiled from administrative records and the Census Bureau's Company Organization Survey program. The establishment level data should represent a complete enumeration of all establishments in scope for the Economic Census and not subject to sampling error. However, the data are subject to non-sampling errors.

\section{A2. Export Transaction Data}

We make use of transaction level data on exports collected by the U.S. Census Bureau via the Shippers Export Declaration (currently U.S. Department of Commerce Form 7525-V). The Census Bureau collects export shipments data for all export shipments above $\$ 2,500$. The Shippers Export Declaration (SED) contains information on the firm that ships the exports (Employer Identification Number), detailed 10-digit Harmonized System product code, value, quantity, export destination, date of the transaction, port, mode of transport, and whether the transaction is between related parties. ${ }^{19}$

The datanumber of export transactions range from 13 million in 1993 to 23 million in 2000 and represent the universe of export shipments greater than $\$ 2,500$.

\footnotetext{
${ }^{19}$ For exports, Foreign Trade Statistics Regulations, 30.7(v), define a related party transaction as one between a U.S. exporter and a foreign consignee, where either party owns, directly or indirectly, 10 percent or more of the other party.
} 
The Census Bureau imputes a total value for low-value exports. We exclude these imputed records.

\section{A2.1. Canada Data Exchange}

The data for exports to Canada is not collected through the Shippers Export Declaration. To reduce reporting burden for U.S. and Canadian firms, the U.S. and Canada exchange import transaction information. The U.S. uses Canadian import transaction from the U.S. as export transaction to Canada. These transactions contain the same information as the SEDs with the exception of Employer Identification Number. The Canadian transactions do not contain EIN but instead contain a firm name field.

Exports to Canada account for approximately 35 percent of total transaction volume and approximately 20 percent of total transaction value.

\section{A3. Import Transaction Data}

We make use of transaction level data on imports collected by U.S. Customs and Border Protection via import declarations (including current U.S. Customs Forms 7501 and 7533). U.S. Customs collects import shipments data for all import shipments above $\$ 2,000$ ( $\$ 250$ for certain quota items). The Customs forms contain information on the firm that imports (Employer Identification Number), detailed 10-digit Harmonized System product code, value, quantity, country of origin, date of the transaction, port, mode of transport, and whether the transaction is between related parties. ${ }^{20}$

The number of import transactions range from 16 million in 1993 to 33 million in 2000 and represent the universe of import shipments greater than $\$ 2,000$. The Census Bureau imputes a total value for low-value imports. We exclude these imputed records.

\footnotetext{
${ }^{20}$ For imports, Section 402(e) of the Tariff Act of 1930 defines related party trade to include transactions between parties with various types of relationships including "any person directly or indirectly, owning, controlling or holding power to vote, 6 percent of the outstanding voting stock or shares of any organization."
} 


\section{A4. Standard Statistical Establishment List (SSEL)/Business Register}

We make use of Employer Identification information and business name information from the Census Bureau Business Register (also called the Standard Statistical Establishment List (SSEL)). The SSEL contains records for all private entities except households. The SSEL carries information on the business name, address, Employer Identification Number (EIN), and information on the industry and employment at the entity. The SSEL also contains information on the firm or enterprise that owns the entity. We make use of the EIN and name information to match firm identifiers to the import and export transaction data. We use the SSEL because it contains name, EIN, and firm level information and because it represents the largest possible universe of firms.

\section{A5. Longitudinal Business Database (LBD)}

To construct firm information (employment and industrial activity), we use the Longitudinal Business Database (LBD). The LBD is a longitudinal version of the information contained in the SSEL. The LBD represents a significant improvement on the raw information contained in the SSEL in that it constructs longitudinal linkages for all establishments and enhances industry code information (among other improvements). See Jarmin and Miranda (2002) for more details.

We use establishments in the LBD that are considered in scope for the Economic Censuses and the County Business Patterns program. We restrict our analysis to industries that are in scope to the Economic Census/CBP program because industries that are not in scope for the Economic Censuses are not broken out into establishments and the Census Bureau does not devote the same resources to these industries so the data quality is more suspect. Jarmin and Miranda report that currently, out of scope industries include: Agriculture, Forestry and Fishing (SIC Division A), railroads (SIC 40), U.S. Postal Service (SIC 43), Certified Passenger Air Carriers (part of SIC 4512), Elementary and Secondary Schools (SIC 821), Colleges and Universities (SIC 822), Labor Organizations (SIC 863), Political Organizations (SIC 865), Religious Organizations (SIC 866), and Public Administration (SIC Di-

vision J). Most government owned or operated entities are outside the scope of the 
Economic Census. While some import and export trade transactions are matched to SSEL entities that are not in scope for the Economic Census, the value of trade associated with these entities is quite small (approximately 3-5 percent).

We use information from the LBD to construct firm level measures of employment and industrial activity and exploit the longitudinal nature of the LBD to examine firm birth and death rates.

\section{A6. Import Transaction Matching}

The import transaction data contain a field for the Employer Identification Number (EIN), so matching to the SSEL is relatively straightforward. The match rates of import transactions to the SSEL are typically in the 80 percent range and the share of matched import value is typically above 80 percent. The largest classes of unmatched import transactions are import transactions where the EIN is not in the SSEL or the EIN field is blank. Non-employers are not included in the SSEL, so import transactions with Social Security Numbers (SSN) as the firm identifier will not match to the SSEL. The other large category of non-matches is import transaction where the EIN field is blank representing about 3-5 percent of import transactions and import value.

Once the match to the SSEL is made via the EIN, firm level identifiers are applied to the import transaction data. These firm level identifiers are then used to match to firm level information constructed from the LBD. Detailed match rate information on import transactions and import value is presented in the top panel of Table 20.

\section{A\%. Export Transaction Matching}

Exports to countries other than Canada contain EIN information and are relatively straightforward to match to the SSEL. For exports to Canada, we first perform an automated name match using the name field on the export transaction and the business name field on the SSEL. Subsequent to the automated matching, we do hand matching for non-matched high value exporters to Canada. After these three phases of matching, we match approximately 70-75 percent of transactions and 75-80 
percent of value. $^{21}$

The largest classes of unmatched export transactions are again export transactions where the EIN is not in the SSEL or the EIN field is blank. The unmatched export transactions where the EIN field is blank represent about 7-10 percent of export transactions and export value. Detailed match rate information on export transactions and export value is presented in the bottom panel of Table 20 .

\section{A8. Country-Income Groups}

We use the 2003 World Bank classification of countries by their per capita income for both years of our sample. The per capita income cutoffs for the four groups are $\$ 765$ or less, $\$ 766$ to $\$ 3,035, \$ 3,036$ to $\$ 9,385$ and $\$ 9,386$ or more. For a list of countries and their World Bank income group,see

http://www.worldbank.org/data/countryclass/countryclass.html.

Taiwan, Israel and Czechoslovakia (1993 only) were not in the World Bank listing and were allocated to the upper middle, upper, and lower middle country income groups respectively. Smaller trading partners of the U.S., i.e. some small countries and country subdivisions, e.g. territories, that were missing per capita income information in the World Bank data were omitted from the country income group analysis.

\footnotetext{
${ }^{21}$ These match rates represent slightly lower volume match rates than the Census Bureau's Foreign Trade Division reports for its "Profile of U.S. Exporting Companies" program. The Foreign Trade Division reports that it matches approximately $78 \%$ of value in 1992 . We do not have access to the algorithm used by FTD or the matched files they produced, however, based on conversations with FTD staff, we believe that our algorithm is more conservative than theirs (reducing the number of false positive matches). For our analytical purposes, we believe that a more conservative approach is appropriate.
} 
Employment (Mill) at Trading Firms

\begin{tabular}{l|cc|cc} 
& \multicolumn{2}{|c|}{1993} & \multicolumn{2}{c}{2000} \\
& Employment & Share* (\%) & Employment & Share* (\%) \\
\hline Firms that trade & 38.1 & 40.0 & 47.9 & 41.9 \\
Firms that export & 34.6 & 36.3 & 45.0 & 39.4 \\
Firms that import & 30.8 & 32.3 & 37.7 & 33.0 \\
Firms that export and import & 27.3 & 28.7 & 34.8 & 30.4 \\
Firms that just export & 7.3 & 7.7 & 10.2 & 8.9 \\
Firms that just import & 3.5 & 3.7 & 2.9 & 2.5 \\
\hline
\end{tabular}

Notes: Table reports the amount of employment (in millions of workers) and share of total civilian U.S.employment at private firms. For a more detailed description of the firm and employment data see Section 3 and the Appendix. The categories are not mutually exclusive, i.e. the bottom three rows sum to the first row, as do the second and the sixth, and similarly for the third and fifth rows.

Table 1: Employment at Firms Engaged in Trade 


\begin{tabular}{|c|c|c|c|c|c|c|}
\hline \multirow[b]{3}{*}{ Firm Type } & \multicolumn{6}{|c|}{ Breakdown of Firms } \\
\hline & \multicolumn{2}{|c|}{1993} & \multicolumn{2}{|c|}{2000} & \multicolumn{2}{|c|}{ Change 1993 to 2000} \\
\hline & Firms & $\%$ of Total & 2000 & $\%$ of Total & Firms & Percent \\
\hline Exporters & 130,072 & 2.6 & 167,217 & 3.1 & 37,145 & 29 \\
\hline Importers & 86,294 & 1.7 & 117,792 & 2.2 & 31,498 & 37 \\
\hline Exporters \& Importers & 43,206 & 0.9 & 60,587 & 1.1 & 17,381 & 40 \\
\hline Multinational Exporters & 23,293 & 0.5 & 39,141 & 0.7 & 15,848 & 68 \\
\hline Multinational Importers & 19,141 & 0.4 & 24,324 & 0.4 & 5,183 & 27 \\
\hline Multinational Exporters \& Importers & 7,772 & 0.2 & 10,556 & 0.2 & 2,784 & 36 \\
\hline Total Firms & $4,987,145$ & 100.0 & $5,474,639$ & 100.0 & 487,494 & 10 \\
\hline
\end{tabular}

Table 2: Breakdown of Trading Firms 


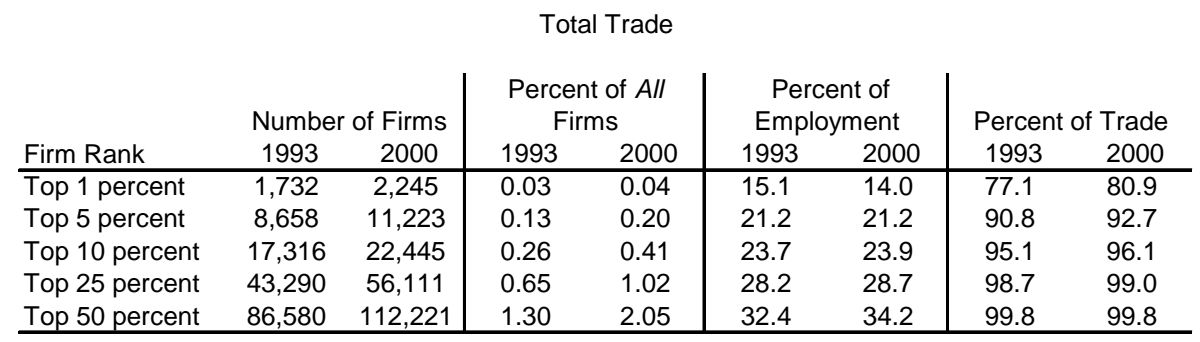

\begin{tabular}{|c|c|c|c|c|c|c|c|c|}
\hline \multirow[b]{2}{*}{ Firm Rank } & \multicolumn{2}{|c|}{ Number of Firms } & \multicolumn{2}{|c|}{$\begin{array}{l}\text { Percent of All } \\
\text { Firms }\end{array}$} & \multicolumn{2}{|c|}{$\begin{array}{c}\text { Percent of } \\
\text { Employment }\end{array}$} & \multicolumn{2}{|c|}{ Percent of Exports } \\
\hline & 1993 & 2000 & 1993 & 2000 & 1993 & 2000 & 1993 & 2000 \\
\hline Top 1 percent & 1,301 & 1,673 & 0.03 & 0.03 & 11.8 & 11.0 & 78.2 & 80.9 \\
\hline Top 5 percent & 6,504 & 8,361 & 0.13 & 0.15 & 17.7 & 17.6 & 91.8 & 93.0 \\
\hline Top 10 percent & 13,008 & 16,722 & 0.26 & 0.31 & 21.5 & 20.8 & 95.6 & 96.3 \\
\hline Top 25 percent & 32,518 & 41,805 & 0.65 & 0.76 & 26.0 & 27.0 & 98.7 & 98.9 \\
\hline Top 50 percent & 65,036 & 83,609 & 1.30 & 1.53 & 30.5 & 32.7 & 99.7 & 99.8 \\
\hline
\end{tabular}

Imports

\begin{tabular}{|c|c|c|c|c|c|c|c|c|}
\hline \multirow[b]{2}{*}{ Firm Rank } & \multicolumn{2}{|c|}{ Number of Firms } & \multicolumn{2}{|c|}{$\begin{array}{l}\text { Percent of } A l l \\
\quad \text { Firms }\end{array}$} & \multicolumn{2}{|c|}{$\begin{array}{l}\text { Percent of } \\
\text { Employment }\end{array}$} & \multicolumn{2}{|c|}{ Percent of Imports } \\
\hline & 1993 & 2000 & 1993 & 2000 & 1993 & 2000 & 1993 & 2000 \\
\hline Top 1 percent & 863 & 1,179 & 0.02 & 0.02 & 11.5 & 11.0 & 72.7 & 77.6 \\
\hline Top 5 percent & 4,315 & 5,891 & 0.09 & 0.11 & 16.7 & 16.3 & 88.2 & 90.8 \\
\hline Top 10 percent & 8,630 & 11,782 & 0.17 & 0.22 & 18.9 & 18.5 & 93.4 & 95.0 \\
\hline Top 25 percent & 21,574 & 29,453 & 0.43 & 0.54 & 22.1 & 21.7 & 98.2 & 98.6 \\
\hline & & & 0.87 & 1.08 & 25.6 & 25.5 & 99.7 & 99.8 \\
\hline
\end{tabular}

Notes: Table reports the number of firms, percent of all U.S. firms, percent of employment and percent of U.S. trade for firms which are responsible for the top 1, 5, 10, 25, and 50 percentiles of the total trade, export and import distributions, respectively.

Table 3: Export and Import Concentration Across Firms 


\begin{tabular}{|c|c|c|c|c|c|c|c|c|}
\hline \multicolumn{9}{|c|}{ Exports } \\
\hline \multirow[b]{2}{*}{ Products } & \multicolumn{2}{|c|}{ Share of Firms (\%) } & \multicolumn{2}{|c|}{ Share of Value (\%) } & \multicolumn{2}{|c|}{$\begin{array}{c}\text { Related-Party } \\
\text { Value Share (\%) }\end{array}$} & \multicolumn{2}{|c|}{$\begin{array}{c}\text { Employment } \\
\text { Share (\%) }\end{array}$} \\
\hline & 1993 & 2000 & 1993 & 2000 & 1993 & 2000 & 1993 & 2000 \\
\hline 0 & & & & & & & 64 & 61 \\
\hline 1 & 41.2 & 36.2 & 1.1 & 0.6 & 0.3 & 0.1 & 4.0 & 4.1 \\
\hline 2 & 16.8 & 15.5 & 1.2 & 0.7 & 0.2 & 0.2 & 2.5 & 2.2 \\
\hline $3-4$ & 16.3 & 15.6 & 2.9 & 1.4 & 0.6 & 0.4 & 2.7 & 2.5 \\
\hline $5-9$ & 14.2 & 15.3 & 6.0 & 3.0 & 2.5 & 1.1 & 3.9 & 4.5 \\
\hline $10+$ & 11.6 & 17.4 & 88.9 & 94.3 & 96.5 & 98.2 & 23.3 & 26.1 \\
\hline
\end{tabular}

\begin{tabular}{|c|c|c|c|c|c|c|c|c|}
\hline \multirow[b]{3}{*}{ Products } & \multicolumn{6}{|c|}{ Imports } & & \\
\hline & \multicolumn{2}{|c|}{ Share of Firms (\%) } & \multicolumn{2}{|c|}{ Share of Value (\%) } & \multicolumn{2}{|c|}{$\begin{array}{c}\text { Related-Party } \\
\text { Value Share (\%) }\end{array}$} & \multicolumn{2}{|c|}{$\begin{array}{c}\text { Employment } \\
\text { Share (\%) }\end{array}$} \\
\hline & 1993 & 2000 & 1993 & 2000 & 1993 & 2000 & 1993 & 2000 \\
\hline 0 & & & & & & & 68 & 67 \\
\hline 1 & 32.1 & 31.6 & 0.8 & 0.7 & 0.2 & 0.2 & 3.8 & 3.5 \\
\hline 2 & 15.1 & 15.2 & 1.1 & 1.1 & 0.4 & 0.3 & 1.9 & 2.8 \\
\hline $3-4$ & 15.7 & 15.9 & 2.5 & 1.9 & 0.8 & 0.8 & 2.3 & 2.4 \\
\hline $5-9$ & 16.3 & 16.5 & 5.2 & 4.1 & 2.3 & 1.6 & 2.8 & 2.9 \\
\hline $10+$ & 20.8 & 20.8 & 90.4 & 92.1 & 96.3 & 97.1 & 21.5 & 21.4 \\
\hline
\end{tabular}

Notes: Table reports percent of firms, share of value produced by firms, and share of employment by firms according to the number of products they import and export in 1993 and 2000.

Table 4: Share of Firms, Value and Employment by Number of Products Exported or Imported Per Firm 


\begin{tabular}{|c|c|c|c|c|c|c|}
\hline \multirow[b]{3}{*}{ Products } & \multicolumn{4}{|c|}{ Exports } & & \\
\hline & \multicolumn{2}{|c|}{$\begin{array}{l}\text { Workers } \\
\text { Per Firm }\end{array}$} & \multicolumn{2}{|c|}{$\begin{array}{l}\text { Value Per } \\
\text { Firm }(\$ 000)\end{array}$} & \multicolumn{2}{|c|}{$\begin{array}{c}\text { Value Per } \\
\text { Worker }(\$ 000)\end{array}$} \\
\hline & 1993 & 2000 & 1993 & 2000 & 1993 & 2000 \\
\hline 1 & 71 & 77 & 66 & 60 & 0.9 & 0.8 \\
\hline 2 & 107 & 96 & 182 & 161 & 1.7 & 1.7 \\
\hline $3-4$ & 121 & 108 & 456 & 322 & 3.8 & 3.0 \\
\hline $5-9$ & 200 & 201 & 1,093 & 714 & 5.5 & 3.5 \\
\hline $10+$ & 1,477 & 1,025 & 19,806 & 19,762 & 13.4 & 19.3 \\
\hline
\end{tabular}

Imports

\begin{tabular}{c|cc|cc|cc} 
& \multicolumn{2}{|c|}{ Workers } & \multicolumn{2}{c|}{ Value Per } & \multicolumn{2}{c}{ Value Per } \\
& \multicolumn{2}{|c|}{ Per Firm } & \multicolumn{2}{c}{ Firm $(\$ 000)$} & \multicolumn{2}{c}{ Worker $(\$ 000)$} \\
Products & 1993 & 2000 & 1993 & 2000 & 1993 & 2000 \\
\hline 1 & 131 & 108 & 132 & 193 & 1.0 & 1.8 \\
2 & 136 & 179 & 383 & 619 & 2.8 & 3.5 \\
$3-4$ & 164 & 146 & 812 & 1,023 & 5.0 & 7.0 \\
$5-9$ & 192 & 170 & 1,623 & 2,086 & 8.5 & 12.3 \\
$10+$ & 1,142 & 996 & 22,290 & 37,172 & 19.5 & 37.3 \\
\hline
\end{tabular}

Notes: Table reports average employment per firm, export or import value per firm and export or import value per worker across firms according to the number of products they export or import in 1993 and 2000.

Table 5: Distribution of Per Firm and Per Worker Statistics by Number of Products Exported or Imported Per Firm 


\begin{tabular}{|c|c|c|c|c|c|c|c|c|}
\hline \multicolumn{9}{|c|}{ Exports } \\
\hline \multirow{2}{*}{$\begin{array}{l}\text { Destination } \\
\text { or Source } \\
\text { Countries }\end{array}$} & \multicolumn{2}{|c|}{ Share of Firms (\%) } & \multicolumn{2}{|c|}{ Share of Value (\%) } & \multicolumn{2}{|c|}{$\begin{array}{c}\text { Related-Party } \\
\text { Value Share (\%) }\end{array}$} & \multicolumn{2}{|c|}{$\begin{array}{c}\text { Employment } \\
\text { Share (\%) }\end{array}$} \\
\hline & 1993 & 2000 & 1993 & 2000 & 1993 & 2000 & 1993 & 2000 \\
\hline 0 & & & & & & & 64 & 61 \\
\hline 1 & 60.3 & 56.6 & 5.9 & 3.7 & 3.4 & 1.7 & 7.9 & 7.7 \\
\hline 2 & 13.6 & 14.7 & 2.7 & 2.3 & 1.6 & 1.2 & 2.7 & 3.1 \\
\hline $3-4$ & 10.5 & 11.8 & 4.0 & 3.2 & 2.1 & 1.6 & 3.1 & 4.2 \\
\hline $5-9$ & 8.3 & 9.3 & 5.8 & 5.2 & 4.1 & 2.8 & 3.4 & 5.8 \\
\hline $10+$ & 7.2 & 7.7 & 81.7 & 85.6 & 88.7 & 92.6 & 19.2 & 18.6 \\
\hline
\end{tabular}

\begin{tabular}{|c|c|c|c|c|c|c|c|c|}
\hline \multicolumn{9}{|c|}{ Imports } \\
\hline \multirow{2}{*}{$\begin{array}{l}\text { Destination } \\
\text { or Source } \\
\text { Countries }\end{array}$} & \multicolumn{2}{|c|}{ Share of Firms (\%) } & \multicolumn{2}{|c|}{ Share of Value (\%) } & \multicolumn{2}{|c|}{$\begin{array}{c}\text { Related-Party } \\
\text { Value Share (\%) }\end{array}$} & \multicolumn{2}{|c|}{$\begin{array}{c}\text { Employment } \\
\text { Share (\%) }\end{array}$} \\
\hline & 1993 & 2000 & 1993 & 2000 & 1993 & 2000 & 1993 & 2000 \\
\hline 0 & & & & & & & 68 & 67 \\
\hline 1 & 52.1 & 51.3 & 4.2 & 3.0 & 3.3 & 1.7 & 5.0 & 5.1 \\
\hline 2 & 18.2 & 18.9 & 3.7 & 3.2 & 2.8 & 2.0 & 2.3 & 3.2 \\
\hline 3-4 & 15.3 & 15.4 & 9.0 & 5.6 & 9.3 & 4.2 & 3.3 & 3.1 \\
\hline $5-9$ & 10.3 & 10.2 & 13.5 & 10.6 & 12.8 & 8.2 & 4.0 & 4.9 \\
\hline $10+$ & 4.1 & 4.2 & 69.6 & 77.7 & 71.8 & 83.9 & 17.6 & 16.7 \\
\hline
\end{tabular}

Notes: Table reports percent of firms, share of value produced by firms, and share of employment by firms according to the number of countries with which they trade in 1993 and 2000.

Table 6: Share of Firms, Value and Employment by Number of Source or Destination Countries 


\begin{tabular}{c|cc|cc|cc}
\multicolumn{1}{c}{$\begin{array}{c}\text { Exports } \\
\text { Destination } \\
\text { or Source }\end{array}$} & \multicolumn{2}{c|}{$\begin{array}{c}\text { Workers } \\
\text { Per Firm }\end{array}$} & \multicolumn{2}{c|}{$\begin{array}{c}\text { Value Per } \\
\text { Firm }(\$ 000)\end{array}$} & \multicolumn{2}{c}{$\begin{array}{c}\text { Value Per } \\
\text { Worker }(\$ 000)\end{array}$} \\
Countries & 1993 & 2000 & 1993 & 2000 & 1993 & 2000 \\
\hline 1 & 95 & 93 & 251 & 241 & 2.6 & 2.6 \\
2 & 143 & 145 & 514 & 562 & 3.6 & 3.9 \\
$3-4$ & 218 & 242 & 964 & 980 & 4.4 & 4.0 \\
$5-9$ & 302 & 430 & 1,786 & 2,049 & 5.9 & 4.8 \\
$10+$ & 1,944 & 1,652 & 29,085 & 40,675 & 15.0 & 24.6 \\
\hline
\end{tabular}

\begin{tabular}{|c|c|c|c|c|c|c|}
\hline \multirow{3}{*}{$\begin{array}{l}\text { Destination } \\
\text { or Source } \\
\text { Countries }\end{array}$} & \multicolumn{4}{|c|}{ Imports } & & \\
\hline & \multicolumn{2}{|c|}{$\begin{array}{l}\text { Workers } \\
\text { Per Firm }\end{array}$} & \multicolumn{2}{|c|}{$\begin{array}{l}\text { Value Per } \\
\text { Firm }(\$ 000)\end{array}$} & \multicolumn{2}{|c|}{$\begin{array}{c}\text { Value Per } \\
\text { Worker }(\$ 000)\end{array}$} \\
\hline & 1993 & 2000 & 1993 & 2000 & 1993 & 2000 \\
\hline 1 & 106 & 97 & 416 & 487 & 3.9 & 5.0 \\
\hline 2 & 141 & 163 & 1,041 & 1,437 & 7.4 & 8.8 \\
\hline $3-4$ & 241 & 197 & 3,007 & 3,046 & 12.5 & 15.5 \\
\hline $5-9$ & 431 & 466 & 6,720 & 8,710 & 15.6 & 18.7 \\
\hline $10+$ & 4,713 & 3,815 & 86,412 & 153,956 & 18.3 & 40.4 \\
\hline
\end{tabular}

Notes: Table reports average employment per firm, export or import value per firm and export or import value per worker for firms according to the number of countries with which they trade in 1993 and 2000.

Table 7: Distribution of Per Firm and Per Worker Statistics by Number of Countries With Which Firms Trade 
Exporting

\begin{tabular}{l|cc|cc|cc|cc} 
Income Level of & \multicolumn{2}{|c|}{ Share of Exporters (\%) } & \multicolumn{2}{|c|}{ Employment Share (\%) } & \multicolumn{2}{|c|}{ Employment Per Firm } & \multicolumn{2}{c}{ Share of Exports (\%) } \\
Destination Country & 1993 & 2000 & 1993 & 2000 & 1993 & 2000 & 1993 & 2000 \\
\hline Low & 5.2 & 7.0 & 13.2 & 15.2 & 1,863 & 1,480 & 1.5 & 1.0 \\
Lower Middle & 20.5 & 22.7 & 21.4 & 21.9 & 764 & 660 & 11.6 & 11.1 \\
Upper Middle & 21.4 & 28.6 & 22.4 & 24.7 & 766 & 591 & 14.7 & 19.6 \\
Upper & 88.3 & 85.6 & 35.4 & 37.9 & 293 & 303 & 72.2 & 68.3 \\
\hline
\end{tabular}

Importing

\begin{tabular}{l|cc|cc|cc|ccc} 
Income Level of & \multicolumn{2}{|c|}{ Share of Importers (\%) } & \multicolumn{2}{|c|}{ Employment Share (\%) } & \multicolumn{2}{|c|}{ Employment Per Firm } & \multicolumn{2}{c}{ Share of Imports (\%) } \\
Source Country & 1993 & 2000 & \multicolumn{2}{|c|}{1993} & 2000 & 1993 & 2000 & 1993 & 2000 \\
\hline Low & 8.2 & 10.6 & 12.5 & 13.2 & 1,684 & 1,202 & 2.6 & 3.0 \\
Lower Middle & 30.7 & 38.2 & 21.3 & 22.5 & 763 & 570 & 14.0 & 17.5 \\
Upper Middle & 15.5 & 18.2 & 19.0 & 19.9 & 1,358 & 1,062 & 13.6 & 18.7 \\
Upper & 85.5 & 79.9 & 31.1 & 31.7 & 401 & 385 & 69.7 & 60.8 \\
\hline
\end{tabular}

Notes: Income levels of U.S. trading partners are according to the the 2003 World Bank Income Group classification available at www.worldbank.org. First two columns report the percent of exporting and importing firms that export to and import from at least one country in the noted country-income groups. Subsequent columns report the share of employment, employment per firm and export and import value represented by firms that trade with the at least one country in the noted groups. The sums of all exporter and importe shares as well as the sums of all employment shares for a given year do not equal 100 because firms may may appear in more than one row of the table if they trade with countries of more than one type. The sums of the shares or exports and imports for a given year do sum to 100 because they sum trade flows at the firm-destination country level.

Table 8: Share of Firms Trading with Different Country-Income Groups 


\begin{tabular}{|c|c|c|c|c|c|c|c|c|c|c|}
\hline \multirow{3}{*}{$\begin{array}{l}\text { Firms }(000), \text { Trade Value } \\
\text { (\$Mill) or Employment }(000)\end{array}$} & \multicolumn{10}{|c|}{ Sector Affiliation } \\
\hline & \multicolumn{2}{|c|}{ Goods } & \multicolumn{2}{|c|}{ Goods Plus } & \multicolumn{2}{|c|}{ Wholesale \& Retail } & \multicolumn{2}{|c|}{ Services } & \multicolumn{2}{|c|}{ Other } \\
\hline & 1993 & 2000 & 1993 & 2000 & 1993 & 2000 & 1993 & 2000 & 1993 & 2000 \\
\hline \multirow[t]{2}{*}{ Firms } & 385 & 399 & 4 & 3 & 1,273 & 1,273 & 3,322 & 3,797 & 3 & 2 \\
\hline & 7.7 & 7.3 & 0.1 & 0.1 & 25.5 & 23.2 & 66.6 & 69.4 & 0.1 & 0.0 \\
\hline \multirow[t]{2}{*}{ Exporting Firms } & 49.6 & 58.9 & 1.9 & 1.9 & 53.2 & 68.2 & 25.0 & 37.7 & 0.4 & 0.5 \\
\hline & 38.1 & 35.2 & 1.5 & 1.1 & 40.9 & 40.8 & 19.2 & 22.6 & 0.3 & 0.3 \\
\hline \multirow[t]{2}{*}{ Importing Firms } & 23.1 & 29.4 & 1.3 & 1.4 & 46.8 & 62.7 & 14.9 & 24.1 & 0.3 & 0.3 \\
\hline & 26.7 & 24.9 & 1.5 & 1.2 & 54.2 & 53.2 & 17.2 & 20.4 & 0.3 & 0.2 \\
\hline \multirow[t]{2}{*}{ E\&l Firms } & 16.8 & 21.7 & 1.2 & 1.3 & 20.5 & 29.0 & 4.6 & 8.4 & 0.2 & 0.2 \\
\hline & 38.8 & 35.8 & 2.8 & 2.1 & 47.4 & 47.9 & 10.6 & 13.8 & 0.5 & 0.3 \\
\hline \multirow[t]{2}{*}{ Multinational Exporters } & 10.0 & 17.5 & 0.9 & 1.1 & 8.3 & 14.1 & 4.1 & 6.2 & 0.1 & 0.2 \\
\hline & 42.7 & 44.8 & 3.7 & 2.9 & 35.6 & 36.1 & 17.4 & 15.7 & 0.6 & 0.5 \\
\hline \multirow[t]{2}{*}{ Multinational Importers } & 5.7 & 7.3 & 0.7 & 0.7 & 10.0 & 12.3 & 2.7 & 3.9 & 0.1 & 0.1 \\
\hline & 29.9 & 30.1 & 3.4 & 2.9 & 52.1 & 50.6 & 14.0 & 16.0 & 0.6 & 0.4 \\
\hline \multirow[t]{2}{*}{ Multinational E\&l } & 3.5 & 4.9 & 0.5 & 0.6 & 3.0 & 3.9 & 0.7 & 1.1 & 0.1 & 0.1 \\
\hline & 45.3 & 46.4 & 7.0 & 5.9 & 38.0 & 36.9 & 8.8 & 10.0 & 0.9 & 0.8 \\
\hline Export Value & $\begin{array}{c}202,600 \\
60.5\end{array}$ & $\begin{array}{c}382,800 \\
62.8\end{array}$ & $\begin{array}{c}50,720 \\
15.1\end{array}$ & $\begin{array}{c}117,100 \\
19.2\end{array}$ & $\begin{array}{c}42,470 \\
12.7\end{array}$ & $\begin{array}{c}63,510 \\
10.4\end{array}$ & $\begin{array}{c}35,920 \\
10.7\end{array}$ & $\begin{array}{c}43,330 \\
7.1\end{array}$ & $\begin{array}{c}3,239 \\
1.0\end{array}$ & $\begin{array}{c}3,088 \\
0.5\end{array}$ \\
\hline Import Value & $\begin{array}{c}170,400 \\
38.5\end{array}$ & $\begin{array}{l}397,100 \\
40.1\end{array}$ & $\begin{array}{c}89,270 \\
20.2\end{array}$ & $\begin{array}{l}214,200 \\
21.6\end{array}$ & $\begin{array}{c}139,200 \\
31.5\end{array}$ & $\begin{array}{c}269,900 \\
27.3\end{array}$ & $\begin{array}{c}36,560 \\
8.3\end{array}$ & $\begin{array}{c}86,690 \\
8.8\end{array}$ & $\begin{array}{c}6,942 \\
1.6\end{array}$ & $\begin{array}{c}21,980 \\
2.2\end{array}$ \\
\hline \multirow[t]{2}{*}{ Related-Party Exports } & 75,120 & 128,700 & 25,770 & 51,270 & 9,380 & 10,510 & 8,161 & 7,703 & 912 & 772 \\
\hline & 62.9 & 64.7 & 21.6 & 25.8 & 7.9 & 5.3 & 6.8 & 3.9 & 0.8 & 0.4 \\
\hline \multirow[t]{2}{*}{ Related-Party Imports } & 96,820 & 248,200 & 58,270 & 133,000 & 50,280 & 95,260 & 5,157 & 15,400 & 3,464 & 19,770 \\
\hline & 45.2 & 48.5 & 27.2 & 26.0 & 23.5 & 18.6 & 2.4 & 3.0 & 1.6 & 3.9 \\
\hline \multirow[t]{2}{*}{ Employment } & 18,026 & 18,554 & 4,167 & 4,207 & 24,023 & 28,409 & 47,849 & 62,149 & 1,187 & 940 \\
\hline & 18.9 & 16.2 & 4.4 & 3.7 & 25.2 & 24.9 & 50.2 & 54.4 & 1.2 & 0.8 \\
\hline Average Employment / Firm & 47 & 46 & 1131 & 1354 & 19 & 22 & 14 & 16 & 372 & 381 \\
\hline
\end{tabular}

Table 9: Breakdown of Firms, Trade and Employment by Firm Activity 


\begin{tabular}{cc|cccc}
\multicolumn{1}{c}{ Exporters } \\
$\begin{array}{c}\text { Export } \\
\text { Relationship }\end{array}$ & $\begin{array}{c}\text { Import } \\
\text { Relationship }\end{array}$ & \multicolumn{2}{c}{ Firms } & \multicolumn{2}{c}{ Firms (\%) } \\
\hline AL & None & 77,329 & 89,273 & 59 & 53 \\
AL & AL & 23,588 & 31,243 & 18 & 19 \\
RP & None & 9,537 & 17,357 & 7 & 10 \\
AL & RP & 5,862 & 7,560 & 5 & 5 \\
RP & AL & 5,984 & 11,228 & 5 & 7 \\
RP & RP & 7,772 & 10,556 & 6 & 6 \\
\hline & & 130,072 & 167,217 & 100 & 100
\end{tabular}

\begin{tabular}{cc|cccc}
\multicolumn{1}{c}{ Import } & Export & \multicolumn{2}{c}{ Firms } & \multicolumn{2}{c}{ Firms (\%) } \\
Relationship & Relationship & 1993 & 2000 & 1993 & 2000 \\
\hline AL & None & 37,581 & 51,017 & 44 & 43 \\
AL & AL & 23,588 & 31,243 & 27 & 27 \\
RP & None & 5,507 & 6,208 & 6 & 5 \\
AL & RP & 5,862 & 7,560 & 7 & 6 \\
RP & AL & 5,984 & 11,228 & 7 & 10 \\
RP & RP & 7,772 & 10,556 & 9 & 9 \\
\hline
\end{tabular}

Notes: Table summarizes the distribution of exporters and importers according to their export and import relationships. These relationships can be either arms-length (AL) or via related parties (RP).

Table 10: Distribution of Trading Firms According to Their Export and Import Relationships 


\begin{tabular}{|c|c|c|c|c|c|c|c|c|}
\hline \multirow[b]{2}{*}{$\begin{array}{l}\text { Trading Partner } \\
\text { Income Level }\end{array}$} & \multicolumn{2}{|c|}{ Exporter Type } & \multicolumn{2}{|c|}{ Exporters (\%) } & \multicolumn{2}{|c|}{ Importer Type } & \multicolumn{2}{|c|}{ Importers (\%) } \\
\hline & $\begin{array}{c}\text { Export } \\
\text { Relationship }\end{array}$ & $\begin{array}{c}\text { Import } \\
\text { Relationship }\end{array}$ & 1993 & 2000 & $\begin{array}{c}\text { Import } \\
\text { Relationship }\end{array}$ & $\begin{array}{c}\text { Export } \\
\text { Relationship }\end{array}$ & 1993 & 2000 \\
\hline \multirow[t]{6}{*}{ Low } & $\mathrm{AL}$ & None & 3 & 4 & $\mathrm{AL}$ & None & 7 & 10 \\
\hline & $A L$ & $\mathrm{AL}$ & 5 & 6 & $A L$ & $\mathrm{AL}$ & 8 & 10 \\
\hline & RP & None & 7 & 7 & RP & None & 8 & 11 \\
\hline & $\mathrm{AL}$ & $\mathrm{RP}$ & 4 & 6 & $A L$ & $\mathrm{RP}$ & 6 & 10 \\
\hline & $\mathrm{RP}$ & $\mathrm{AL}$ & 16 & 18 & $\mathrm{RP}$ & $\mathrm{AL}$ & 11 & 13 \\
\hline & $\mathrm{RP}$ & $\mathrm{RP}$ & 21 & 26 & $\mathrm{RP}$ & $\mathrm{RP}$ & 13 & 17 \\
\hline \multirow[t]{6}{*}{ Lower Middle } & $\mathrm{AL}$ & None & 13 & 14 & $\mathrm{AL}$ & None & 29 & 36 \\
\hline & $A L$ & $\mathrm{AL}$ & 24 & 26 & $\mathrm{AL}$ & $\mathrm{AL}$ & 31 & 38 \\
\hline & $\mathrm{RP}$ & None & 26 & 21 & $\mathrm{RP}$ & None & 29 & 34 \\
\hline & $\mathrm{AL}$ & $\mathrm{RP}$ & 23 & 26 & $\mathrm{AL}$ & $\mathrm{RP}$ & 27 & 37 \\
\hline & $\mathrm{RP}$ & $\mathrm{AL}$ & 49 & 47 & $\mathrm{RP}$ & $\mathrm{AL}$ & 36 & 41 \\
\hline & $\mathrm{RP}$ & $\mathrm{RP}$ & 51 & 57 & $\mathrm{RP}$ & $\mathrm{RP}$ & 40 & 51 \\
\hline \multirow[t]{6}{*}{ Upper Middle } & $\mathrm{AL}$ & None & 14 & 20 & $\mathrm{AL}$ & None & 10 & 12 \\
\hline & $A L$ & $\mathrm{AL}$ & 24 & 30 & $\mathrm{AL}$ & $\mathrm{AL}$ & 14 & 17 \\
\hline & $\mathrm{RP}$ & None & 26 & 28 & $\mathrm{RP}$ & None & 16 & 16 \\
\hline & $\mathrm{AL}$ & $\mathrm{RP}$ & 26 & 33 & $\mathrm{AL}$ & $\mathrm{RP}$ & 19 & 22 \\
\hline & RP & $\mathrm{AL}$ & 49 & 54 & $\mathrm{RP}$ & $\mathrm{AL}$ & 23 & 24 \\
\hline & $\mathrm{RP}$ & $\mathrm{RP}$ & 57 & 68 & $\mathrm{RP}$ & $\mathrm{RP}$ & 37 & 45 \\
\hline \multirow[t]{6}{*}{ Upper } & $\mathrm{AL}$ & None & 87 & 82 & $\mathrm{AL}$ & None & 80 & 72 \\
\hline & $A L$ & $\mathrm{AL}$ & 88 & 85 & $\mathrm{AL}$ & $\mathrm{AL}$ & 87 & 82 \\
\hline & $\mathrm{RP}$ & None & 88 & 91 & $\mathrm{RP}$ & None & 86 & 83 \\
\hline & $\mathrm{AL}$ & $\mathrm{RP}$ & 90 & 87 & $A L$ & $\mathrm{RP}$ & 91 & 87 \\
\hline & $\mathrm{RP}$ & $\mathrm{AL}$ & 93 & 95 & $\mathrm{RP}$ & $\mathrm{AL}$ & 92 & 90 \\
\hline & $\mathrm{RP}$ & $\mathrm{RP}$ & 96 & 96 & $\mathrm{RP}$ & $\mathrm{RP}$ & 95 & 95 \\
\hline
\end{tabular}

Notes: Table reports the distribution of trading firms according to both their export and import relationships and the income level of their trading partners. Exporting and importing firms are allocated to one of six mutually exclusive categories according to their export and import relationships, which can be either arms-length $(A L)$ or related-party (RP). The first block of columns reports results for exporters and the countries to which they export while the second block of columns reports results for importers and the countries from which they import. The percentages reported in columns 4, 5, 8 and 9 represent the percent of trading firms of each type that export to (columns 3 and 4 ) or import from (columns 8 and 9) at least one country of the noted type. The percentages for any given export and import relationship pair may not sum to 100 percent because firms may trade with countries of more than one income level.

Table 11: Global Engagement and Trading Partner Characteristics 


\begin{tabular}{|c|c|c|c|c|c|c|c|c|}
\hline \multirow[b]{2}{*}{$\begin{array}{l}\text { Trading Partner } \\
\text { Income Level }\end{array}$} & \multicolumn{2}{|c|}{ Exporter Type } & \multicolumn{2}{|c|}{ Export Value (\%) } & \multicolumn{2}{|c|}{ Importer Type } & \multicolumn{2}{|c|}{ Import Value (\%) } \\
\hline & $\begin{array}{c}\text { Export } \\
\text { Relationship }\end{array}$ & $\begin{array}{c}\text { Import } \\
\text { Relationship }\end{array}$ & 1993 & 2000 & $\begin{array}{c}\text { Import } \\
\text { Relationship }\end{array}$ & $\begin{array}{c}\text { Export } \\
\text { Relationship }\end{array}$ & 1993 & 2000 \\
\hline \multirow[t]{6}{*}{ Low } & $\mathrm{AL}$ & None & 2 & 3 & $\mathrm{AL}$ & None & 6 & 8 \\
\hline & $A L$ & $\mathrm{AL}$ & 2 & 3 & $\mathrm{AL}$ & $\mathrm{AL}$ & 4 & 6 \\
\hline & $\mathrm{RP}$ & None & 2 & 2 & RP & None & 9 & 4 \\
\hline & $A L$ & $\mathrm{RP}$ & 2 & 2 & $A L$ & $\mathrm{RP}$ & 3 & 3 \\
\hline & $\mathrm{RP}$ & $A L$ & 1 & 1 & RP & $A L$ & 2 & 7 \\
\hline & $\mathrm{RP}$ & $\mathrm{RP}$ & 1 & 6 & RP & $\mathrm{RP}$ & 2 & 2 \\
\hline \multirow[t]{6}{*}{ Lower Middle } & $\mathrm{AL}$ & None & 16 & 17 & $\mathrm{AL}$ & None & 32 & 32 \\
\hline & $A L$ & $\mathrm{AL}$ & 16 & 18 & $\mathrm{AL}$ & $\mathrm{AL}$ & 32 & 37 \\
\hline & $\mathrm{RP}$ & None & 10 & 11 & RP & None & 15 & 23 \\
\hline & $A L$ & $\mathrm{RP}$ & 16 & 13 & $A L$ & $\mathrm{RP}$ & 29 & 38 \\
\hline & RP & $\mathrm{AL}$ & 9 & 11 & RP & $A L$ & 21 & 28 \\
\hline & $\mathrm{RP}$ & $\mathrm{RP}$ & 11 & 10 & RP & $\mathrm{RP}$ & 10 & 14 \\
\hline \multirow[t]{6}{*}{ Upper Middle } & $\mathrm{AL}$ & None & 17 & 19 & $\mathrm{AL}$ & None & 7 & 9 \\
\hline & $A L$ & $\mathrm{AL}$ & 12 & 18 & $A L$ & $\mathrm{AL}$ & 13 & 11 \\
\hline & RP & None & 18 & 17 & RP & None & 10 & 13 \\
\hline & $\mathrm{AL}$ & $\mathrm{RP}$ & 13 & 23 & $A L$ & $\mathrm{RP}$ & 11 & 16 \\
\hline & $\mathrm{RP}$ & $A L$ & 10 & 18 & RP & $\mathrm{AL}$ & 16 & 12 \\
\hline & $\mathrm{RP}$ & $\mathrm{RP}$ & 15 & 19 & RP & $\mathrm{RP}$ & 14 & 20 \\
\hline \multirow[t]{6}{*}{ Upper } & $\mathrm{AL}$ & None & 66 & 60 & $\mathrm{AL}$ & None & 55 & 51 \\
\hline & $A L$ & $\mathrm{AL}$ & 70 & 61 & $\mathrm{AL}$ & $\mathrm{AL}$ & 50 & 45 \\
\hline & $\mathrm{RP}$ & None & 70 & 70 & RP & None & 67 & 60 \\
\hline & $A L$ & $\mathrm{RP}$ & 69 & 62 & $A L$ & $\mathrm{RP}$ & 58 & 43 \\
\hline & RP & $\mathrm{AL}$ & 79 & 68 & $\mathrm{RP}$ & $\mathrm{AL}$ & 61 & 53 \\
\hline & $\mathrm{RP}$ & $\mathrm{RP}$ & 71 & 65 & $\mathrm{RP}$ & $\mathrm{RP}$ & 74 & 63 \\
\hline
\end{tabular}

Notes: Table reports the distribution of export and impor value according to firms' export and import relationships and the income level of their trading partners. Exporting and importing firms are allocated to one of six mutually exclusive categories according to their export and import relationships, which can be either arms-length (AL) or related-party (RP). The first block of columns reports results for exporters and the countries to which they export while the second block of columns reports results for importers and the countries from which they import. The percentages reported in columns 4, 5, 8 and 9 represent the share of value traded by firms of each type that export to (columns 3 and 4 ) or import from (columns 8 and 9) at least one country of the noted type. The percentages for any given export and import relationship pair sum to 100 percent (e.g. rows 1, 7, 13 and 19) because export and import value are observed at the transaction level.

Table 12: Export and Import Value by Firms' Global Engagement and Trading Partner Characteristics 


\begin{tabular}{l|cc|cc}
\multicolumn{1}{c}{} & \multicolumn{3}{c}{ Multinational Employment (Mill) } \\
& \multicolumn{2}{|c}{1993} & \multicolumn{2}{c}{2000} \\
\hline Multinationals & Employment & Share* (\%) & Employment & Share* (\%) \\
- that export to a related party & 25.5 & 26.7 & 33.3 & 29.1 \\
- that import from a related party & 23.4 & 24.5 & 30.9 & 27.0 \\
- that export to and import from a related party & 19.5 & 20.4 & 23.3 & 20.4 \\
- that just export to a related party & 17.4 & 18.2 & 20.9 & 18.3 \\
- that just import from a related party & 6.0 & 6.3 & 10.0 & 8.8 \\
\hline Notes: Table reports the amount of employment (in millions of workers) at multinational firms in 1993 and \\
2000. The categories are not mutually exclusive, i.e. the bottom three rows sum to the first row, as do the \\
second and the sixth, and similarly for the third and fifth rows. *Employment shares are with respect to total \\
civilian U.S. employment as reported in the Economic Report of the President.
\end{tabular}

Table 13: Employment at Multinationals Engaged in Trade 


\begin{tabular}{|c|c|c|c|c|c|c|c|c|}
\hline \multirow{3}{*}{$\begin{array}{c}\text { Related Party } \\
\text { Share of Trade (\%) }\end{array}$} & \multicolumn{4}{|c|}{ Exports } & \multicolumn{4}{|c|}{ Imports } \\
\hline & \multicolumn{2}{|c|}{1993} & \multicolumn{2}{|c|}{2000} & \multicolumn{2}{|c|}{1993} & \multicolumn{2}{|c|}{2000} \\
\hline & Firms & Value & Firms & Value & Firms & Value & Firms & Value \\
\hline$<0.25$ & 53.0 & 6.7 & 63.9 & 9.7 & 41.9 & 3.3 & 43.1 & 3.5 \\
\hline $0.25-0.75$ & 24.6 & 56.6 & 23.0 & 68.3 & 25.1 & 30.8 & 25.0 & 25.9 \\
\hline$>0.75$ & 22.4 & 36.7 & 13.1 & 22.0 & 33.0 & 66.0 & 31.9 & 70.6 \\
\hline
\end{tabular}

Table 14: Distribution of Multinational Firms and Related-Party Trade by Multinationals' Related-Party Trade Intensity 
Sector Affiliation

\begin{tabular}{|c|c|c|c|c|c|c|c|c|c|c|}
\hline & \multicolumn{2}{|c|}{ Goods } & \multicolumn{2}{|c|}{ Goods Plus } & \multicolumn{2}{|c|}{ Wholesale \& Retail } & \multicolumn{2}{|c|}{ Services } & \multicolumn{2}{|c|}{ Other } \\
\hline & 1993 & 2000 & 1993 & 2000 & 1993 & 2000 & 1993 & 2000 & 1993 & 2000 \\
\hline \multirow[t]{2}{*}{ Firms } & 3,523 & 4,901 & 541 & 626 & 682 & 1,057 & 2,955 & 3,891 & 71 & 81 \\
\hline & 45.3 & 46.4 & 7.0 & 5.9 & 8.8 & 10.0 & 38.0 & 36.9 & 0.9 & 0.8 \\
\hline \multirow[t]{2}{*}{ Export Value } & 173 & 341 & 42 & 114 & 13 & 18 & 17 & 26 & 2 & 2 \\
\hline & 69.9 & 68.0 & 17.1 & 22.7 & 5.3 & 3.6 & 6.9 & 5.2 & 0.9 & 0.4 \\
\hline \multirow[t]{2}{*}{ Import Value } & 155 & 366 & 82 & 209 & 20 & 46 & 73 & 149 & 6 & 21 \\
\hline & 46.1 & 46.2 & 24.4 & 26.4 & 6.0 & 5.8 & 21.6 & 18.8 & 1.9 & 2.7 \\
\hline \multirow[t]{2}{*}{ Related-Party Exports } & 72 & 125 & 20 & 51 & 4 & 5 & 6 & 7 & 1 & 1 \\
\hline & 70.0 & 66.1 & 19.4 & 26.9 & 3.8 & 2.7 & 6.1 & 3.8 & 0.8 & 0.4 \\
\hline \multirow[t]{2}{*}{ Related-Party Imports } & 95 & 244 & 56 & 133 & 4 & 11 & 41 & 79 & 3 & 20 \\
\hline & 47.7 & 50.2 & 28.1 & 27.3 & 1.9 & 2.3 & 20.6 & 16.2 & 1.7 & 4.0 \\
\hline \multirow[t]{2}{*}{ Employment } & 8,018 & 8,510 & 3,131 & 3,334 & 2,349 & 4,682 & 3,232 & 3,974 & 625 & 373 \\
\hline & 46.2 & 40.8 & 18.0 & 16.0 & 13.5 & 22.4 & 18.6 & 19.0 & 3.6 & 1.8 \\
\hline
\end{tabular}

Notes: Table breaks out the number of firms, trading value and employment of the most globally engaged (MGE) firms according to their sector affiliation. Each establishment within a firm possesses a primary industry designation via a four-digit Standard Industrial Classification code. These codes map into three basic firm orientations: Goods (manufacturing, mining, or agriculture), Wholesale \& Retail (wholesale or retail trade) and Services (all remaining sectors). Firms with more than 75 percent of their employees in one of these orientations are assigned to it. Firms where employment in Goods is between 25 percent and 75 percent are assigned to "Goods Plus", and all other firms are assigned to "Other".

Table 15: A Breakdown of The Most Globally Engaged Firms by Activity 


\section{Export Value}

\begin{tabular}{|c|c|c|c|c|}
\hline & \multicolumn{2}{|c|}{$\begin{array}{l}\text { Related-Party } \\
\text { Share (\%) }\end{array}$} & \multicolumn{2}{|c|}{$\begin{array}{c}\text { Most-Globally- } \\
\text { Engaged Share (\% }\end{array}$} \\
\hline & 1993 & 2000 & 1993 & 2000 \\
\hline All countries & 42 & 38 & 74 & 82 \\
\hline Low Income & 14 & 15 & 70 & 64 \\
\hline Lower middle & 19 & 22 & 73 & 78 \\
\hline Upper middle & 53 & 42 & 76 & 83 \\
\hline Upper & 43 & 38 & 73 & 82 \\
\hline
\end{tabular}

Import Value

\begin{tabular}{l|cc|cc} 
& \multicolumn{2}{|c|}{$\begin{array}{c}\text { Related-Party } \\
\text { Share (\%) }\end{array}$} & \multicolumn{2}{c}{$\begin{array}{c}\text { Most-Globally- } \\
\text { Engaged Share (\%) }\end{array}$} \\
& 1993 & 2000 & 1993 & 2000 \\
\hline All countries & 59 & 61 & 76 & 80 \\
\hline Low Income & 14 & 24 & 61 & 59 \\
Lower middle & 27 & 35 & 56 & 64 \\
Upper middle & 63 & 68 & 78 & 88 \\
Upper & 64 & 66 & 80 & 83 \\
\hline
\end{tabular}

Notes: Table summarizes the activity of multinational firms

that both export to and import from related parties, i.e., the "most globally engaged" firms. Table reports the share of trade by these firms that is intra-firm to the particular country-income group as well as the share of total trade to that country-income group accounted for by the most globally engaged firms.

Table 16: Intra-firm Trade of the Most Globally-Engaged Firms 


\begin{tabular}{|c|c|c|c|c|c|c|c|}
\hline \multirow[b]{3}{*}{ Subset of Firms } & \multicolumn{6}{|c|}{ Number of Firms } & \multirow[b]{3}{*}{2000} \\
\hline & & \multirow[b]{2}{*}{$\begin{array}{c}\text { Exiting } \\
\text { Firms }\end{array}$} & \multirow[b]{2}{*}{$\begin{array}{c}\text { New } \\
\text { Entrants }\end{array}$} & \multicolumn{3}{|c|}{ Continuing Firms } & \\
\hline & 1993 & & & $\begin{array}{c}\text { Trade in } \\
\text { Both Years }\end{array}$ & $\begin{array}{c}\text { Non-Traders } \\
\text { That Become } \\
\text { Traders }\end{array}$ & $\begin{array}{c}\text { Traders } \\
\text { That Become } \\
\text { Non-Traders }\end{array}$ & \\
\hline Firms that Export & 130,072 & 48,269 & 64,352 & 53,830 & 49,035 & 27,973 & 167,217 \\
\hline Firms that Import & 86,294 & 33,273 & 52,698 & 36,458 & 28,656 & 16,583 & 117,792 \\
\hline Firms that Both E\&l & 43,206 & 15,106 & 22,299 & 18,987 & 19,301 & 9,113 & 60,587 \\
\hline Multinational Exporters & 23,293 & 8,566 & 12,656 & 8,034 & 18,451 & 6,693 & 39,141 \\
\hline Multinational Importers & 19,141 & 7,119 & 10,406 & 7,212 & 6,706 & 4,810 & 24,324 \\
\hline Multinational E\&l & 7,772 & 2,584 & 3,317 & 3,377 & 3,862 & 1,811 & 10,556 \\
\hline All Firms & $4,987,145$ & $2,354,216$ & $2,841,710$ & $2,632,929$ & na & na & $5,474,639$ \\
\hline
\end{tabular}

Share of Firms Relative to 1993 Level (\%)

\begin{tabular}{|c|c|c|c|c|c|c|c|}
\hline \multirow[b]{2}{*}{ Subset of Firms } & \multirow[b]{2}{*}{1993} & \multirow[b]{2}{*}{$\begin{array}{r}\text { Exiting } \\
\text { Firms }\end{array}$} & \multirow[b]{2}{*}{$\begin{array}{c}\text { New } \\
\text { Entrants }\end{array}$} & \multicolumn{3}{|c|}{ Continuing Firms } & \multirow[b]{2}{*}{2000} \\
\hline & & & & $\begin{array}{l}\text { Trade in } \\
\text { Both Years }\end{array}$ & $\begin{array}{c}\text { Non-Traders } \\
\text { That Become } \\
\text { Traders }\end{array}$ & $\begin{array}{c}\text { Traders } \\
\text { That Become } \\
\text { Non-Traders }\end{array}$ & \\
\hline Firms that Export & 100 & 37 & 49 & 41 & 38 & 22 & 129 \\
\hline Firms that Import & 100 & 39 & 61 & 42 & 33 & 19 & 137 \\
\hline Firms that Both E\&l & 100 & 35 & 52 & 44 & 45 & 21 & 140 \\
\hline Multinational Exporters & 100 & 37 & 54 & 34 & 79 & 29 & 168 \\
\hline Multinational Importers & 100 & 37 & 54 & 38 & 35 & 25 & 127 \\
\hline Multinational E\&I & 100 & 33 & 43 & 43 & 50 & 23 & 136 \\
\hline All Firms & 100 & 47 & 57 & 53 & na & na & 110 \\
\hline
\end{tabular}

Notes: Table summarizes dynamics across different subsets of firms between 1993 and 2000. The overall growth in the number of firms of each type is decomposed across columns. Upper panel displays firm counts while lower panel displays the share of each count relative to the 1993 total. Columns 1 and 7 report the number of firms of each type in 1993 and 2000 , respectively. Note that the subsets of firms reported in each row are not mutually exclusive, i.e. some of the firms that export also import, and vice versa. Columns 2, 3 and 4 report the number of 1993 firms that exit, the number of new firms entering between 1993 and 2000 and the number of 1993 firms present in both years, respectively. Column 5 and 6 report the number of firms that switch their trading status between 1993 and 2000 . Column 5 indicates the number of continuing firms that did not engage in the noted activity in 1993 but start doing so by 2000 . Column 6 reports the opposite.

Table 17: Decomposition of the Number of Trading Firms, 1993 to 2000 


\begin{tabular}{|c|c|c|c|c|c|c|c|}
\hline \multicolumn{8}{|c|}{ Change in Employment } \\
\hline \multirow[b]{2}{*}{ Subset of Firms } & \multirow[b]{2}{*}{1993} & \multirow[b]{2}{*}{$\begin{array}{r}\text { Exiting } \\
\text { Firms }\end{array}$} & \multirow[b]{2}{*}{$\begin{array}{c}\text { New } \\
\text { Entrants }\end{array}$} & \multicolumn{3}{|c|}{ Continuing Firms } & \multirow[b]{2}{*}{2000} \\
\hline & & & & $\begin{array}{c}\text { Trade in } \\
\text { Both Years }\end{array}$ & $\begin{array}{c}\text { Non-Traders } \\
\text { That Become } \\
\text { Traders }\end{array}$ & $\begin{array}{c}\text { Traders } \\
\text { That Become } \\
\text { Non-Traders }\end{array}$ & \\
\hline Firms that Export & 34.6 & 6.6 & 5.9 & 6.1 & 7.5 & 2.5 & 45.0 \\
\hline Firms that Import & 30.8 & 5.6 & 4.7 & 4.7 & 7.0 & 4.0 & 37.7 \\
\hline Firms that Both E\&I & 27.3 & 4.6 & 4.1 & 3.9 & 6.8 & 2.7 & 34.8 \\
\hline Multinational Exporters & 23.4 & 3.3 & 3.2 & 3.4 & 7.0 & 2.7 & 30.9 \\
\hline Multinational Importers & 19.5 & 2.6 & 2.3 & 1.4 & 5.6 & 2.8 & 23.3 \\
\hline Multinational E\&l & 17.4 & 2.1 & 1.8 & 1.2 & 5.4 & 2.8 & 20.9 \\
\hline All Firms & 95.3 & 28.2 & 29.1 & 18.1 & na & na & 114.3 \\
\hline
\end{tabular}

Change in Employment Relative to 1993 Level (\%)

\begin{tabular}{|c|c|c|c|c|c|c|c|}
\hline \multirow[b]{2}{*}{ Subset of Firms } & \multirow[b]{2}{*}{1993} & \multirow[b]{2}{*}{$\begin{array}{r}\text { Exiting } \\
\text { Firms }\end{array}$} & \multirow[b]{2}{*}{$\begin{array}{c}\text { New } \\
\text { Entrants }\end{array}$} & \multicolumn{3}{|c|}{ Continuing Firms } & \multirow[b]{2}{*}{2000} \\
\hline & & & & $\begin{array}{l}\text { Trade in } \\
\text { Both Years }\end{array}$ & $\begin{array}{c}\text { Non-Traders } \\
\text { That Become } \\
\text { Traders }\end{array}$ & $\begin{array}{c}\text { Traders } \\
\text { That Become } \\
\text { Non-Traders }\end{array}$ & \\
\hline Firms that Export & 100 & 19.2 & 17.0 & 17.7 & 21.7 & 7.1 & 130.2 \\
\hline Firms that Import & 100 & 18.2 & 15.3 & 15.2 & 22.8 & 12.8 & 122.3 \\
\hline Firms that Both E\&I & 100 & 16.8 & 14.9 & 14.3 & 25.0 & 9.9 & 127.4 \\
\hline Multinational Exporters & 100 & 14.3 & 13.7 & 14.5 & 30.0 & 11.6 & 132.3 \\
\hline Multinational Importers & 100 & 13.6 & 12.0 & 7.0 & 28.6 & 14.4 & 119.5 \\
\hline Multinational E\&l & 100 & 11.9 & 10.5 & 6.6 & 31.3 & 16.3 & 120.3 \\
\hline All Firms & 100 & 29.6 & 30.5 & 19.0 & na & na & 120.0 \\
\hline
\end{tabular}

Notes: Table decomposes overall employment growth across the noted subsets of firms between 1993 and 2000 . The upper panel displays changes in employment for the noted subset of firms while the lower panel normalizes these employment changes according to their respective 1993 levels. Columns 1 and 7 report total employment by the noted subset of firms in 1993 and 2000, respectively. Note that the subsets of firms reported in each row are not mutually exclusive, i.e. some of the firms that export also import, and vice versa. Columns 2, 3 and 4 report the number of workers employed by firms that exit, by firms that enter between 1993 and 2000 and by firms present in both years, respectively. Column 5 and 6 report the number of workers employed by firms that switch their trading status between 1993 and 2000 . Column 5 is computed for firms that did not engage in the noted activity in 1993 but start doing so by 2000. Column 6 reports the opposite.

Table 18: Decomposition of Employment Across Trading Firm Types, 1993 to 2000 


\begin{tabular}{lcccc}
\multicolumn{5}{c}{ Employment (Mill) } \\
Transition Type & 1993 & 2000 & Change & \% Change \\
\hline Not Exporting to Exporting & 3.9 & 7.5 & 3.6 & 94.3 \\
Not Importing to Importing & 3.6 & 7.0 & 3.4 & 93.9 \\
Not E\&I to E\&l & 3.3 & 6.8 & 3.5 & 108.3 \\
\hline Exporting to Not Exporting & 2.5 & 2.2 & -0.3 & -12.3 \\
Importing to Not Importing & 4.0 & 3.3 & -0.7 & -16.6 \\
E\&I to Not E\&I & 2.7 & 2.4 & -0.3 & -10.1 \\
\hline Continuing Exporters & 25.5 & 31.6 & 6.1 & 24.0 \\
Continuing Importers & 21.3 & 25.9 & 4.7 & 22.0 \\
Continuing E\&l & 20.0 & 23.9 & 3.9 & 19.5 \\
\hline Continuing Non-Exporters & 35.3 & 43.9 & 8.6 & 24.5 \\
Continuing Non-Importers & 38.2 & 48.9 & 10.7 & 27.9 \\
Continuing Non-E\&I & 41.1 & 52.0 & 10.9 & 26.6 \\
\hline Notes: Table reports the employment level of surviving firms that continue trading or switch to \\
being traders of the noted type from being non-traders, and vice versa, between 1993 and 2000. \\
E\&l refers to firms that both import and export.
\end{tabular}

Table 19: Employment Growth by Firms' Trading Status, 1993 to 2000 


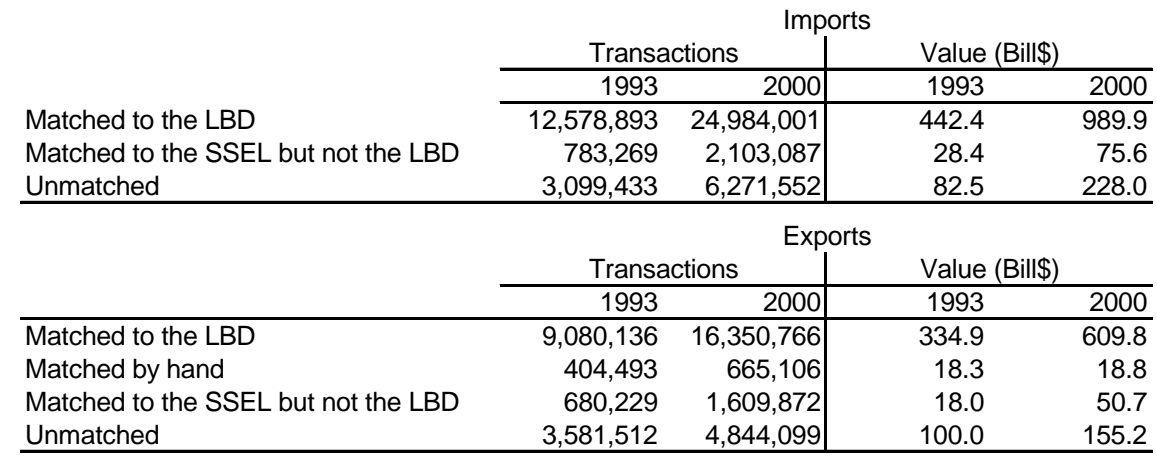

Table 20: Matching Statistics for Imports and Exports 


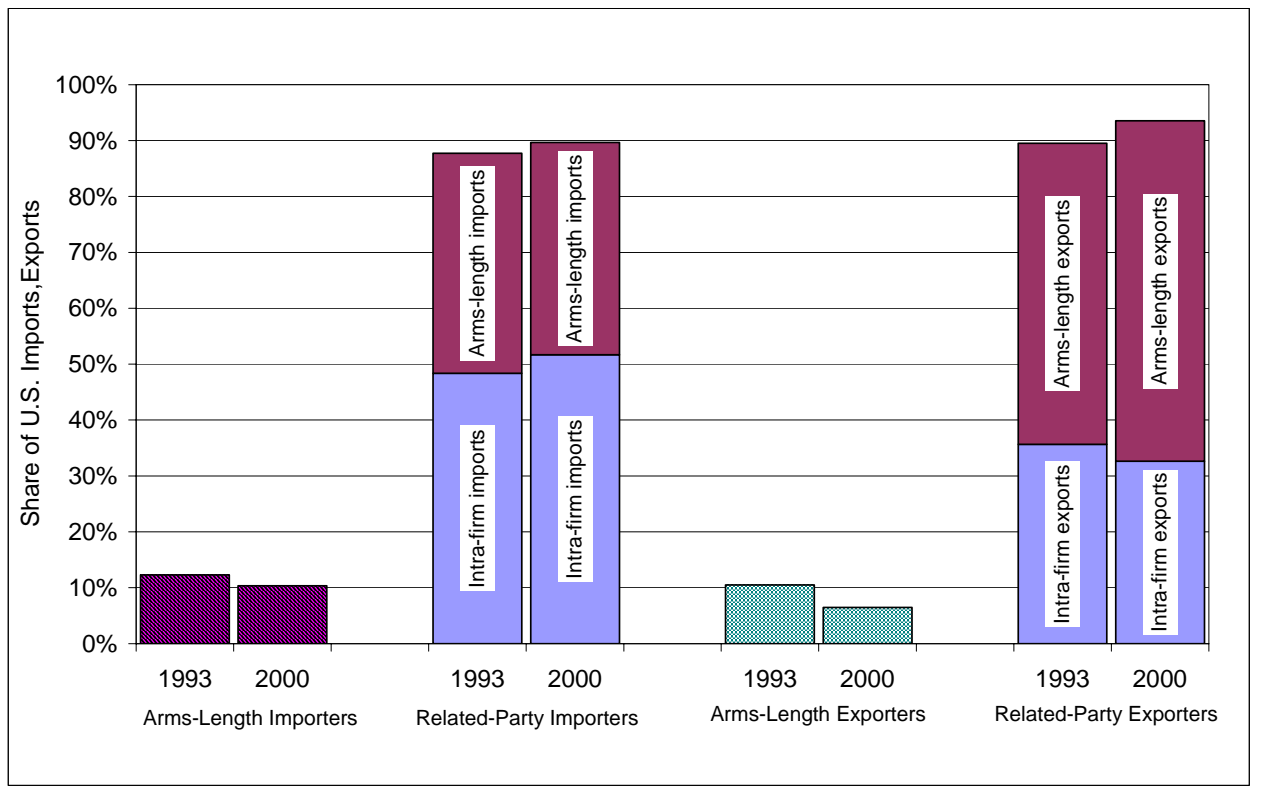

Figure 1: The Share of U.S Trade That Flows Through Multinational Firms 


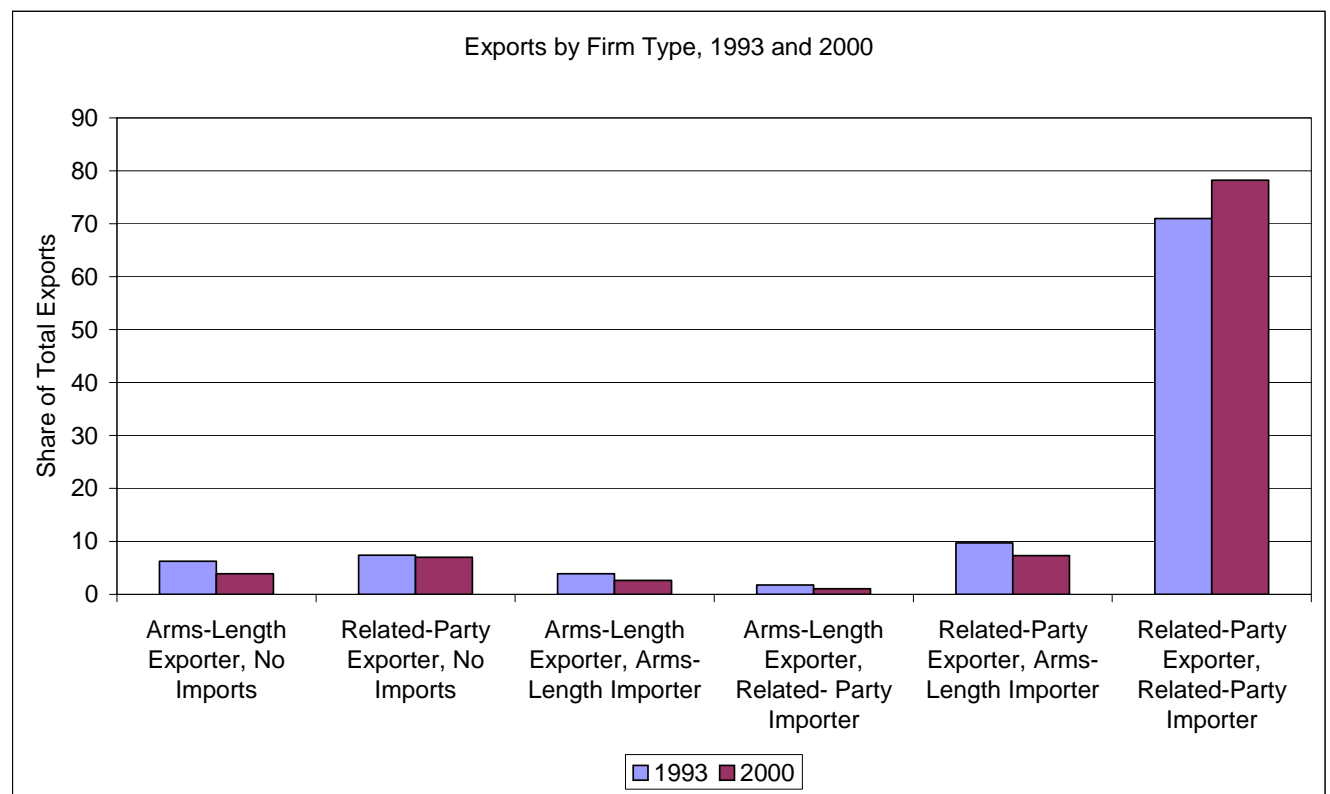

Figure 2: Global Engagement and Exports 


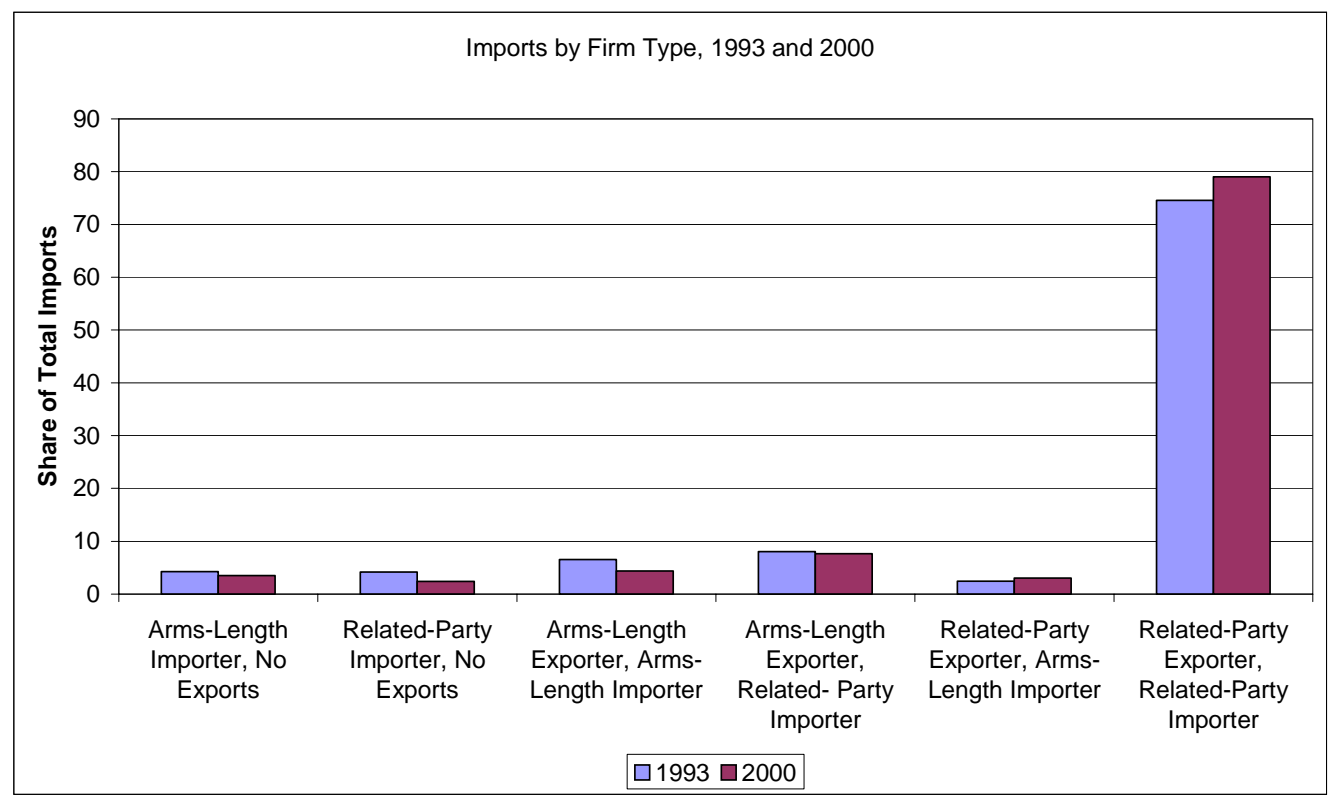

Figure 3: Global Engagement and Imports 